\title{
Manipulating Protein Acetylation in Breast Cancer: A Promising Approach in Combination with Hormonal Therapies?
}

\author{
Aurélien Linares, ${ }^{1}$ Florence Dalenc, ${ }^{2}$ Patrick Balaguer, ${ }^{1}$ Nathalie Boulle, ${ }^{3}$ \\ and Vincent Cavailles ${ }^{1}$ \\ ${ }^{1}$ IRCM, Institut de Recherche en Cancérologie de Montpellier, INSERM, U896, Université Montpellier1, \\ CRLC Val d'Aurelle Paul Lamarque, Montpellier, 34298, France \\ ${ }^{2}$ CRLC Claudius Regaud, 31052 Toulouse Cedex, France \\ ${ }^{3}$ Laboratoire de Biologie Cellulaire et Hormonale, CHRU Arnaud de Villeneuve, 34090 Montpellier, France \\ Correspondence should be addressed to Vincent Cavailles, vincent.cavailles@inserm.fr
}

Received 13 July 2010; Accepted 3 November 2010

Academic Editor: Minoru Yoshida

Copyright ( $) 2011$ Aurélien Linares et al. This is an open access article distributed under the Creative Commons Attribution License, which permits unrestricted use, distribution, and reproduction in any medium, provided the original work is properly cited.

\begin{abstract}
Estrogens play an essential role in the normal physiology of the breast as well as in mammary tumorigenesis. Their effects are mediated by two nuclear estrogen receptors, $\mathrm{ER} \alpha$ and $\beta$, which regulate transcription of specific genes by interacting with multiprotein complexes, including histone deacetylases (HDACs). During the past few years, HDACs have raised great interest as therapeutic targets in the field of cancer therapy. In breast cancer, several experimental arguments suggest that HDACs are involved at multiple levels in mammary tumorigenesis: their expression is deregulated in breast tumors; they interfere with ER signaling in intricate ways, restoring hormone sensitivity in models of estrogen resistance, and they clinically represent new potential targets for HDACs inhibitors (HDIs) in combination with hormonal therapies. In this paper, we will describe these different aspects and underline the clinical interest of HDIs in the context of breast cancer resistance to hormone therapies (HTs).
\end{abstract}

\section{Introduction}

1.1. Breast Cancer and Hormonal Therapies. Breast cancer is the most common malignancy and the second most common cause of cancer-related death amongst women in France, Western Europe and North America. About 70\% to $80 \%$ of infiltrating breast carcinoma are estrogen receptor alpha $(\mathrm{ER} \alpha)$ positive, thus offering clinicians the opportunity of hormonal therapies (HTs) in adjuvant and/or metastatic situation. Modulation of estrogen signaling pathways using antiestrogens (such as Tamoxifen or Fulvestrant) or more recently aromatase inhibitors (such as Exemestane, Letrozole, or Anastrozole) was indeed one of the first recognized targeted therapies and is currently the first-line treatment for $\operatorname{ER} \alpha$ positive tumors [1]. The effectiveness of HTs is directly linked to the expression and functionality of ER $\alpha$. Several retrospective studies and clinical trials have demonstrated that tumors expressing both $\mathrm{ER} \alpha$ and progesterone receptor (PR) respond significantly better to HTs than those with low receptor expression [2, 3]. Among patients who have a tumor expressing both $\mathrm{ER} \alpha$ and PR, a benefit from HTs is seen in about $60 \%$ of cases, but the initial response is often not durable, since tumors become resistant to hormonal manipulation, leading to an "endocrine-resistant disease". Moreover, patients with breast carcinoma lacking $\operatorname{ER} \alpha$ (ER $\alpha$ negative) will not benefit from these therapies, as the expected efficiency of HTs in this situation is less than $10 \%$.

Definition of the specific genetic lesions and molecular processes that determine clinical endocrine resistance is still incomplete. Candidate molecular pathways of intrinsic and acquired resistance to HTs emphasize the importance of signaling networks which control cell proliferation (e.g., acting via epidermal growth factor receptor type 2 (HER2) or insulin-like growth factor-1 receptor (IGF-1R)) or survival (through molecules such as Bad or Bcl-2) [4, 5]. In addition, polymorphisms in metabolizing enzymes such as the hepatic drug-metabolizing cytochrome P450 2D6 (CYP2D6) may 
reduce the therapeutic benefit from tamoxifen (for a review, see [6]). Today, the main challenges in mammary cancer research are thus the development of more specific biomarkers to predict response or resistance to hormonal therapy and the development of new combined targeted therapies of hormone therapy-insensitive or therapy-resistant tumors.

1.2. Nuclear ER Signaling. Estrogens, like many other hormones, elicit numerous biological responses. They play a major role in the development and maintenance of the female reproductive tract (including the mammary glands) and are also involved in breast tumorigenesis. They act on target tissues through binding to two ER isoforms ( $\mathrm{ER} \alpha$ and $\operatorname{ER} \beta$ ), which are members of the nuclear hormone receptor (NR) superfamily [7]. Upon interaction with ERs, estrogens induce a conformational change, which favors receptor dimerization and recruitment to promoter elements either directly through their DNA-binding domain or indirectly through interaction with other transcription factors. ER complexes then recruit transcriptional coregulators (coactivators and corepressors) to increase or inhibit target gene transcription [7]. In most cases, transcriptional cofactors are recruited as multiprotein complexes that could act either sequentially or simultaneously, depending on the considered gene. Many transcriptional coregulators of NRs exhibit enzymatic activities that participate in their mechanism of action. For example, several coactivators-CBP/p300, pCAF, SRC-1, and SRC-3 - are acetyltransferases that are able to modify various lysine residues located in the amino terminal tails of histones. Conversely, inhibitory complexes associated with corepressors, contain histone deacetylases (HDACs) whose activity counteracts that of acetyltransferases (HATs). Some other enzymatic activities-including kinases or methyltransferases-displayed by coregulators are also able to modify histone lysines, arginines, or serines. All these posttranslational modifications interfere with each other and represent signals that enable binding of proteins involved in the transcriptional control of gene expression. From a clinical point of view, transcription therapies targeting pathological epigenetic modifications are very promising approaches to improve cancer treatment (see below).

\section{Histone Deacetylases and Inhibitors}

2.1. Acetylation of Chromatin and Nonchromatin Proteins. Acetylation and deacetylation of the $\mathcal{E}$-amino group of Lys residue $\left(\mathrm{N}^{\varepsilon}\right)$ is a reversible reaction catalysed by the opposing actions of Lys acetyltransferases and Lys deacetylases. This modification, also described in bacteria, has been first extensively studied in the context of chromatin and histone modifications. As noted above, acetylation and deacetylation of the N-terminal tails of histones contribute to the "histone code" which defines part of the epigenetic landscape involved in the regulation of gene expression. It is now known that in addition to histones and transcription factors, $\mathrm{N}^{\varepsilon}$-acetylation target numerous other proteins, such as proteins involved in cell signaling, DNA repair, metabolism, apoptosis, cytoskeleton, and protein folding (see also Section 5 of this paper).
$\mathrm{N}$ acetyl Lysine may serve as a docking structure for bromodomain, a protein domain that has the ability to recognize acetyl-lysine motifs. $\mathrm{N}^{\varepsilon}$-acetylation may either enhance or decrease the function of the protein targeted, depending on the presence of other posttranslational modifications on the protein (such as phosphorylation and methylation) and the effects of $\mathrm{N}^{\varepsilon}$-acetylation on protein/protein interactions [8].

Although both enzymes are involved in the modulation of protein acetylation, HDACs have been extensively studied as therapeutic targets, in particular in the context of cancer, while few studies have been performed on the clinical benefits of regulating HATs.

2.2. The HDAC Family. Up to now, eighteen human HDACs have been identified. They are divided into 4 families according to sequence homologies: class I (HDAC1, -2, -3 , and -8) and class II (HDAC4, -5, -6, -7, -9, and -10) are homologous to the yeast histone deacetylases Rpd3 and Hda1, respectively, and share some degree of sequence homology. Class IV HDAC11 has been discovered more recently and shows similarities to both yeast Rpd3 and Hda1. Class I, II, and IV enzymes present a zinc ion-dependent catalytic domain. By contrast, class III enzymes (called sirtuins) are homologous to the yeast protein Sir2 and use NAD as a cofactor [9].

In the past few years, the crystal structure of the catalytic domain of human class I HDAC8 and class II HDAC4 and HDAC7 has been elucidated and several knockout mice targeting various HDACs have been generated, thus providing insights into their structure and physiological functions [1013]. The diversity of HDACs suggests differential roles for the various classes of enzymes depending on tissues or cell lines. Accordingly, HDACs have been linked to cell cycle and proliferation and to the differentiation of various tissues. In addition to these physiological roles, the HDAC family has been involved in the physiopathology of human diseases including cancer. Fusion proteins containing HDACs complexes as well as deregulation of protein acetylation and/ or HDACs expression have indeed been shown for various hematopoietic or solid tumors $[14,15]$. Such findings have long encouraged the development of HDAC inhibitors as anticancer agents.

2.3. HDAC Inhibitors. Sodium butyrate $(\mathrm{NaBu})$ was the first HDAC inhibitor (HDI) to be discovered in the late seventies, being initially found to have antitumor activity by inducing cell differentiation. Since then, various HDIs with different structures and potencies have been synthesized or purified from natural sources, and their effects as anticancer drugs are now widely documented. In 2006, suberoylanilide hydroxamic acid (SAHA or Vorinostat) was the first HDI approved by the FDA for the treatment of cutaneous T-cell lymphoma [16]. Today, the development of HDIs for the treatment of cancer is still ongoing and 80 phases I and II clinical trials are currently underway to validate these drugs alone or in association with other therapies in patients with hematological or solid tumors (see Section 6) [17, 18].

Different studies using cDNA array approaches have shown that around $10 \%$ of genes are modulated by HDIs, 
with differences in the genes altered linked to the cell model, the time of culture, the concentration, and the HDIs used $[19,20]$. Nevertheless, HDIs have been shown to have potent antitumor effects in vitro and in vivo on various cancer types affecting tumor cells at multiple levels: induction of cell cycle arrest, apoptosis and differentiation, inhibition of angiogenesis, inhibition of cell migration and invasion, and increase in antitumor immunity, response to radio- and chemotherapies (for reviews see [14, 21, 22]).

One of the challenges for the next years will be the development of more selective HDIs that would target specific HDAC isoforms to offer the patients the best therapeutic responses with the lowest toxicity. Specific HDIs have thus been described targeting class I HDACs and class II HDACs or HDAC8, some of them being tested in clinical trials, such as class I-specific MGCD0103 (Mocetinostat) in Hodgkin lymphoma [23]. Another challenge will be to search for biomarkers of clinical response to HDIs [24]. Some biomarkers have already been proposed such as histone $\mathrm{H} 3$ and $\mathrm{H} 4$ acetylation in tissues or peripheral blood mononuclear cells, HDAC2 tissue expression [25], gene expression profiles [26], or more recently expression of HR23B, a protein involved in the targeting of ubiquitinylated proteins to the proteasome [27]. Despite encouraging results, the identification of potential biomarkers of response to HDIs is critically needed for future trials that will combine these drugs with endocrine therapy.

\section{HDACs and Breast Cancer}

3.1. HDAC Expression in Breast Cancers. HDAC expression in breast tumors has not been described for all members of the HDAC family, but mostly concerns class I HDAC1, -2 , and -3 and class IIb HDAC6 at the protein and/or mRNA levels. Analysis of their prognostic significance in breast carcinoma has been performed in some studies (see below and [15] for a review).

Regarding mammary tumor progression, Suzuki et al. [28] reported a marked reduction in histone acetylation from normal mammary epithelium to ductal carcinoma in situ (DCIS) whereas most cases showed similar levels of acetylation in DCIS as compared to invasive ductal carcinoma. This suggests that alterations of histone acetylation are an early event in breast tumor progression. The authors also described a significant but smaller decrease in HDAC1, HDAC2, and HDAC6 protein levels during tumor progression. Greater reductions in HDAC1 protein levels were observed from normal to DCIS in estrogen-receptor negative and high-grade breast tumors (Table 1). According to the authors, such discrepancy (i.e., concomitant decrease in HDAC expression and histone acetylation) could be linked to the relative activities of both HATs and HDACs, as altered expression of HATs has been described in various cancers. It is also possible that the expression of other HDACs, not analyzed in this study, is increased during breast cancer progression, thus encountering for the global reduction in histone acetylation.

Analyzing invasive breast carcinoma, Krusche et al. detected HDAC1 protein expression in the nucleus of
TABLE 1: Expression of HDACs in relation with ER.

\begin{tabular}{|c|c|c|}
\hline HDAC & HDAC expression & References \\
\hline \multirow[t]{3}{*}{ HDAC1 } & $\begin{array}{l}\text { Reduced expression from } \\
\text { normal to DCIS (ER- tumors) }\end{array}$ & {$[28]$} \\
\hline & $\begin{array}{l}\text { Correlation with ER } \\
\text { expression }\end{array}$ & {$[29]$} \\
\hline & $\begin{array}{l}\text { High level of mRNA in ER+ } \\
\text { breast cancers }\end{array}$ & {$[30]$} \\
\hline \multirow[t]{2}{*}{ HDAC2 } & $\begin{array}{l}\text { Locus deletion in ER+ PR+ } \\
\text { breast cancers }\end{array}$ & {$[31]$} \\
\hline & $\begin{array}{l}\text { Underexpressed in ER+ breast } \\
\text { cancers }\end{array}$ & {$[32-55]^{*}$} \\
\hline \multirow[t]{3}{*}{ HDAC3 } & $\begin{array}{l}\text { Overexpressed in ER+ breast } \\
\text { cancers }\end{array}$ & {$[44]^{*}$} \\
\hline & $\begin{array}{l}\text { Correlation with ER } \\
\text { expression }\end{array}$ & {$[29]$} \\
\hline & $\begin{array}{l}\text { Underexpressed in ER+ breast } \\
\text { cancer }\end{array}$ & {$[56]^{*}$} \\
\hline \multirow[t]{2}{*}{ HDAC4 } & $\begin{array}{l}\text { Overexpressed in ER+ breast } \\
\text { cancers }\end{array}$ & {$[45,47]^{*}$} \\
\hline & $\begin{array}{l}\text { Underexpressed in ER+ breast } \\
\text { cancers }\end{array}$ & {$[38,43,53,54,57]^{*}$} \\
\hline HDAC5 & $\begin{array}{l}\text { Overexpressed in ER+ breast } \\
\text { cancers }\end{array}$ & $\begin{array}{c}{[34,37,39,51,52,54} \\
57,58]^{*}\end{array}$ \\
\hline \multirow[t]{4}{*}{ HDAC6 } & $\begin{array}{l}\text { Overexpressed in ER+ breast } \\
\text { cancers }\end{array}$ & {$[45,47,51,53]^{*}$} \\
\hline & $\begin{array}{l}\text { High level of mRNA in ER+ } \\
\text { breast cancer }\end{array}$ & {$[59]$} \\
\hline & $\begin{array}{l}\text { Increased expression in ER+ } \\
\text { breast cancer }\end{array}$ & {$[60]$} \\
\hline & $\begin{array}{l}\text { Underexpressed in ER+ breast } \\
\text { cancers }\end{array}$ & {$[32,34,37,50-52]^{*}$} \\
\hline HDAC7 & $\begin{array}{l}\text { Overexpressed in ER+ breast } \\
\text { cancers }\end{array}$ & $\begin{array}{c}{[36-38,40,44,45,47} \\
53,58,61]^{*}\end{array}$ \\
\hline HDAC8 & $\begin{array}{l}\text { Underexpressed in ER+ breast } \\
\text { cancers }\end{array}$ & {$[45,47,56,62]^{*}$} \\
\hline HDAC9 & $\begin{array}{l}\text { Underexpressed in ER+ breast } \\
\text { cancers }\end{array}$ & $\begin{array}{c}{[32,34,35,37-} \\
40,45,47,52-54,58]^{*} \\
\end{array}$ \\
\hline HDAC10 & $\begin{array}{l}\text { Overexpressed in ER+ ductal } \\
\text { breast cancer }\end{array}$ & {$[48]^{*}$} \\
\hline HDAC11 & $\begin{array}{l}\text { Overexpressed in ER+ breast } \\
\text { cancers }\end{array}$ & $\begin{array}{c}35,37- \\
40,43,45,47,51- \\
53,56,58]^{*} \\
\end{array}$ \\
\hline SIRT1 & $\begin{array}{l}\text { Overexpressed in ER+ breast } \\
\text { cancers }\end{array}$ & {$[38,40,46,52,53]^{*}$} \\
\hline
\end{tabular}

References with * were obtained from the Oncomine database. Increased or decreased expression was considered statistically significant at $P<.05$.

mammary luminal epithelial cells, but not in basal cells, and observed the presence of nuclear HDAC1 and HDAC3 proteins in $40 \%$ and $44 \%$ of breast tumors, respectively. They also found that HDAC1 and 3 protein levels correlated significantly with estrogen and progesterone receptors expression and that $\mathrm{HDACl}$ was an independent prognostic marker of better disease-free survival (DFS), but not overall survival (OS) in patients with invasive breast carcinoma 
[29]. Similarly, Zhang et al. analyzed HDAC1 mRNA levels in invasive breast tumors and showed that HDAC1 mRNA levels were elevated in ER and PR positive tumors. They also found that patients with breast tumors displaying high levels of HDAC1 mRNA levels tended to have a better prognosis; however, in this study, HDAC1 was not found to be an independent prognostic marker of either DFS or OS [59].

Several studies have focused on HDAC6 expression in breast carcinoma. The rational for such studies relies on initial results showing that HDAC6 was as an estrogenresponsive gene identified by a microarray approach and that it could modulate mammary tumor cell motility in vitro $[60,63]$. More recently, Lee et al. also showed that HDAC6 was required for anchorage-independent growth of breast tumor cells [64]. HDAC6 protein was detected in 65\% [59] and 77\% [60] of breast carcinoma, with a cytoplasmic localization of the protein in both studies. Higher levels of HDAC6 mRNA were found in small, low-grade and ER+, $\mathrm{PR}+$ breast tumors, that is, tumors of better prognosis, but this result was not confirmed at the protein level [59]. When analyzing the different studies, the prognosis significance of HDAC6 expression in invasive breast carcinoma remains controversial [15]. For instance, Yoshida et al. found that high levels of HDAC6 correlated with a negative prognosis survival whereas Zhang et al. showed that high levels of HDAC6 mRNA and protein was linked to improved DFS but not OS $[59,65]$. On the other hand, Saji et al. did not link HDAC6 expression to DFS or OS, but found increased expression of HDAC6 in a subgroup of ER-positive, tamoxifen-responsive breast carcinoma.

Fewer studies have been performed on HDAC2 in breast carcinoma although its expression is frequently altered in cancer $[14,15]$. In a recent analysis of genetic alterations associated with breast cancer subtypes, Hu et al. found deletions/loss of the HDAC2 locus in ER-positive and PR-positive breast tumors, but no data on HDAC2 expression were presented in this study [31]. HDAC2 mutations resulting in loss of HDAC2 protein and resistance to apoptosis induced by HDIs have been described in colon cancer [66]. However, to our knowledge, no mutations in HDAC2 or any other HDACs have been described in breast cancer.

In addition to these published data, we have performed data mining on HDAC expression in breast cancer using the Oncomine database (Compendia Bioscience, Ann Arbor, MI, USA-www.oncomine.org/). As shown in Table 2, the expression of some HDACs appears to be deregulated in breast cancers as compared to normal breast tissues. This is particularly true for HDAC2 and HDAC11 (overexpressed in cancer) or HDAC4-6 and the class III enzyme SIRT1 (underexpressed in cancer). In addition, the same data mining approach reveals that the expression of HDAC3-7, 10, 11, and SIRT1 at the mRNA level is higher in ER-positive breast cancers (Table 1).

In conclusion, although careful analysis of their expression and consequences in breast cancer have not already been performed for all members of the HDAC family, several studies and Oncomine data analysis underline the potential role of HDAC deregulation in breast tumor progression.
TABLE 2: Expression of HDACs in breast cancers.

\begin{tabular}{|c|c|c|c|}
\hline $\begin{array}{l}\text { Enzyme } \\
\text { (locus) }\end{array}$ & Total studies & $\begin{array}{c}\text { Increased } \\
\text { expression in } \mathrm{BC}\end{array}$ & $\begin{array}{c}\text { Decreased } \\
\text { expression in } \mathrm{BC}\end{array}$ \\
\hline $\begin{array}{l}\text { HDAC1 } \\
(1 \mathrm{p} 34)\end{array}$ & 5 & 1 & 1 \\
\hline $\begin{array}{l}\text { HDAC2 } \\
(6 q 21)\end{array}$ & 7 & 5 & 2 \\
\hline $\begin{array}{l}\text { HDAC3 } \\
(5 q 31)\end{array}$ & 5 & 1 & 2 \\
\hline $\begin{array}{l}\text { HDAC4 } \\
(2 \mathrm{q} 37.3)\end{array}$ & 6 & 1 & 5 \\
\hline $\begin{array}{l}\text { HDAC5 } \\
(17 q 21)\end{array}$ & 5 & 1 & 4 \\
\hline $\begin{array}{l}\text { HDAC6 } \\
(\mathrm{Xp} 11.23)\end{array}$ & 8 & 0 & 3 \\
\hline $\begin{array}{l}\text { HDAC7 } \\
(12 \mathrm{q} 13.1)\end{array}$ & 5 & 0 & 1 \\
\hline $\begin{array}{l}\text { HDAC8 } \\
(\mathrm{Xq} 13)\end{array}$ & 5 & 2 & 1 \\
\hline $\begin{array}{l}\text { HDAC9 } \\
(7 \mathrm{p} 21.1)\end{array}$ & 6 & 4 & 2 \\
\hline $\begin{array}{l}\text { HDAC10 } \\
(22 \mathrm{q} 13.31)\end{array}$ & 8 & 0 & 1 \\
\hline $\begin{array}{l}\text { HDAC11 } \\
(3 \mathrm{p} 25.1)\end{array}$ & 6 & 3 & 1 \\
\hline $\begin{array}{l}\text { SIRT1 } \\
(10 \mathrm{q} 21.3)\end{array}$ & 9 & 0 & 3 \\
\hline
\end{tabular}

From Oncomine database (Compendia Bioscience, Ann Arbor, MI, USAwww.oncomine.org/). Differential expression in breast cancer (BC) versus normal breast tissue was considered significant at $P<.05$. Bold numbers correspond to the strongest deregulations.

3.2. Effects of HDI on Breast Cancers-Experimental Data. In breast tumor models, HDIs have potent antiproliferative effects in vitro and in vivo and interfere with estrogen signaling regulating ER $\alpha$ and ER $\beta$ expression and function (see Section 4 and 5).

Various HDI have been shown to inhibit the proliferation of breast tumor cell lines, as well as normal human breast epithelial cells with IC50 ranging from $\mathrm{nM}$ to few $\mathrm{mM}$ depending on the HDIs tested [67-69]. This antiproliferative effect was found to be more pronounced in ER positive breast tumor cells than in ER negative ones [70, 71]. In various tumor models, this effect was in part linked to the induction of the cell cycle inhibitor p21 by HDI [70, 72]. Interestingly, p21 gene was found to more sensitive to HDI in ER positive than in ER negative mammary tumor cells, which may explain the observed difference in inhibition of cell proliferation upon HDI treatment according to the ER status [70]. Moreover, HDI were found to decrease Cyclin D1 expression and stability in mammary tumor cells and to inhibit phosphorylation of the retinoblastoma protein [71, 73-76]. Depending on the cell model, modifications of other cell cycle regulators have also been described including p27 and cyclin B1 [76, 77]. Accordingly, HDI induce cell cycle blockade at the G0-G1 and/or the G2/M level [74, 76-79]. 
TABLE 3: HDACs and estrogen signaling.

\begin{tabular}{|c|c|c|}
\hline HDAC & Effect on estrogen signaling & References \\
\hline \multirow[t]{4}{*}{ HDAC1 } & Recruited to the silenced $\mathrm{ER} \alpha$ promoter & {$[80]$} \\
\hline & Present on ER-target gene promoter region & {$[81]$} \\
\hline & Knockdown reduces ER $\alpha$ levels & {$[82]$} \\
\hline & $\begin{array}{l}\text { Directly interact with } \mathrm{ER} \alpha \text {-suppresses } \mathrm{ER} \alpha \\
\text { activity in } 293 \mathrm{~T} \text { cells }\end{array}$ & {$[83]$} \\
\hline \multirow[t]{2}{*}{ HDAC2 } & Present on ER-target gene promoter region & {$[84]$} \\
\hline & Knockdown reduces ER $\alpha$ levels & {$[82]$} \\
\hline HDAC3 & Present on ER-target gene promoter region & {$[81]$} \\
\hline \multirow[t]{2}{*}{ HDAC4 } & Present on ER-target gene promoter region & {$[85]$} \\
\hline & Binds the $\mathrm{N}$-terminal $\mathrm{A} / \mathrm{B}$ domain of $\mathrm{ER} \alpha$ & {$[86]$} \\
\hline \multirow[t]{3}{*}{ HDAC5 } & Repress ER $\alpha$ promoter via MEF2 & {$[87]$} \\
\hline & $\begin{array}{l}\text { Directly interacts with } \mathrm{ER} \alpha \text {-Represses } \mathrm{ER} \alpha \\
\text { activity }\end{array}$ & \\
\hline & $\begin{array}{l}\mathrm{KO} \text { associated with upregulation of } \mathrm{ER} \alpha \\
\text { signaling }\end{array}$ & \\
\hline \multirow[t]{3}{*}{ HDAC6 } & Knockdown reduces ER $\alpha$ levels & {$[82]$} \\
\hline & Bind the AF2-domain of ER $\alpha$ & {$[88]$} \\
\hline & $\begin{array}{l}\text { Regulates ER } \alpha \text { degradation via hsp90 } \\
\text { acetylation }\end{array}$ & {$[89]$} \\
\hline \multirow[t]{2}{*}{ HDAC7 } & Present on the pS2 gene promoter region & {$[84]$} \\
\hline & $\begin{array}{l}\text { Represses ER } \alpha \text { activity-Required for } \\
\text { E2-dependent repression }\end{array}$ & {$[90]$} \\
\hline \multirow[t]{3}{*}{ HDAC9 } & Repress ER $\alpha$ promoter via MEF2 & {$[87]$} \\
\hline & $\begin{array}{l}\text { Directly interacts with } \mathrm{ER} \alpha \text {-Represses } \mathrm{ER} \alpha \\
\text { activity }\end{array}$ & \\
\hline & $\begin{array}{l}\text { KO associated with upregulation of } \mathrm{ER} \alpha \\
\text { signaling }\end{array}$ & \\
\hline \multirow[t]{2}{*}{ SIRT1 } & Deacetylates ER $\alpha$ in vitro & \\
\hline & Knockdown reduces ER $\alpha$ levels & {$[91]$} \\
\hline
\end{tabular}

Most of these studies have been performed using HDI of broad range specificity. Recently, Duong et al. showed that inhibition of class II HDACs, using specific chemical compounds, also led to inhibition of mammary tumor cells proliferation in a dose-dependent manner, with higher potency in ER-positive than in ER-negative cell lines. In this study, specific inhibition of class II HDACs induced p21 expression, leading a cell-cycle blockade at the G0-G1 level [74]. Thus, although class II HDACs have been linked to cell differentiation, they may also be involved in cell proliferation, at least in this tumor model.

In vitro, HDI were found to induce apoptosis in breast tumor cells expressing or not ER $\alpha$ [74, 77, 92]. Depending on the cell type and/or the HDI used, apoptosis was linked to activation of the intrinsic (mitochondrial) and/or the extrinsic pathway. Some studies have shown upregulation of the proapoptotic Bak and Bim members along with a downregulation of the antiapoptotic survivin, XIAP and Bcl2 proteins in breast tumor cells [79] whereas others have found strong upregulation of the death receptors upon HDI [92, 93]. In addition, HDIs can efficiently sensitize breast cancer cells to TRAIL-mediated death signaling in vitro and in preclinical in vivo models [77, 79, 94-96] and can significantly increase the apoptotic effects of various drugs targeting breast tumors.

HDI are also involved in cell differentiation. For instance, Davis et al. showed that $\mathrm{NaBu}$ induced cell differentiation in normal breast epithelial cell line as well as in breast cancer cells as indicated by accumulation of lipid droplets [67]. Using valproic acid (VPA), Travaglini et al. confirmed this result by measuring milk lipid production in cell cultures and showed that this effect was independent of the mammary cells ER status [76].

The antiproliferative and proapoptotic effects of HDIs observed in vitro were confirmed in preclinical mice or rat breast cancer models [68, 95, 97, 98]. HDIs were indeed shown to have anti-tumor activity in vivo, alone or in combination with other therapies, by inhibiting tumor growth or inducing tumor regression depending on the models, and this was found for ER $\alpha$-expressing [68] as well as ER $\alpha$-negative [98] breast tumor models. Interestingly, Hirokawa et al. further showed that the class I-specific HDI FK228 (depsipeptide or Istodax) was able to inhibit the growth of tamoxifen-resistant MCF-7 xenografts in nude mice (see below clinical studies) [97]. More recently, Palmieri et al. found that Vorinostat prevented the development of brain metastasis using a preclinical model of triple-negative breast cancer [99].

Taken together, these preclinical studies indicate that HDI have anti-tumor effects in breast cancer, targeting $\mathrm{ER} \alpha$-positive and ER-negative cells as well as the most aggressive mammary tumor types (tamoxifen-resistant and triple-negative tumors).

\section{Regulation of ER Expression by HDACs}

During the last decade, several groups have investigated the mechanisms by which HDACs regulate ER expression in breast cancer cells. These studies, which mostly concern ER $\alpha$, have highlighted the multiplicity of the regulations involved (see Table 3 and Figure 1).

4.1. Negative Regulation of ER $\alpha$ Expression. In several ER $\alpha$ expressing human cancer cells from different origin (breast, endometrium, ovary...), treatment with HDAC inhibitors such as trichostatin A (TSA), Vorinostat, FR901228, HCtoxin, VPA, LBH589 (Panobinostat), or NaBu produced a marked decrease in ER $\alpha$ expression at the mRNA and protein levels, which is independent of the presence or absence of ER ligands $[82,100,101]$. The mechanisms of this effect seem to involve different types of regulation which take place both at the transcriptional and posttranscriptional levels.

4.1.1. At the Transcriptional Level. A first level of inhibition of ER $\alpha$ expression takes place at the transcriptional level. Indeed, several studies have reported a decrease in ER $\alpha$ mRNA accumulation upon treatment with various HDAC inhibitors [100-102]. Concomitant treatment by TSA and cycloheximide, a protein synthesis inhibitor, did not affect the observed repression of ER $\alpha$ mRNA accumulation, suggesting a direct role for HDAC activity in the maintenance of 


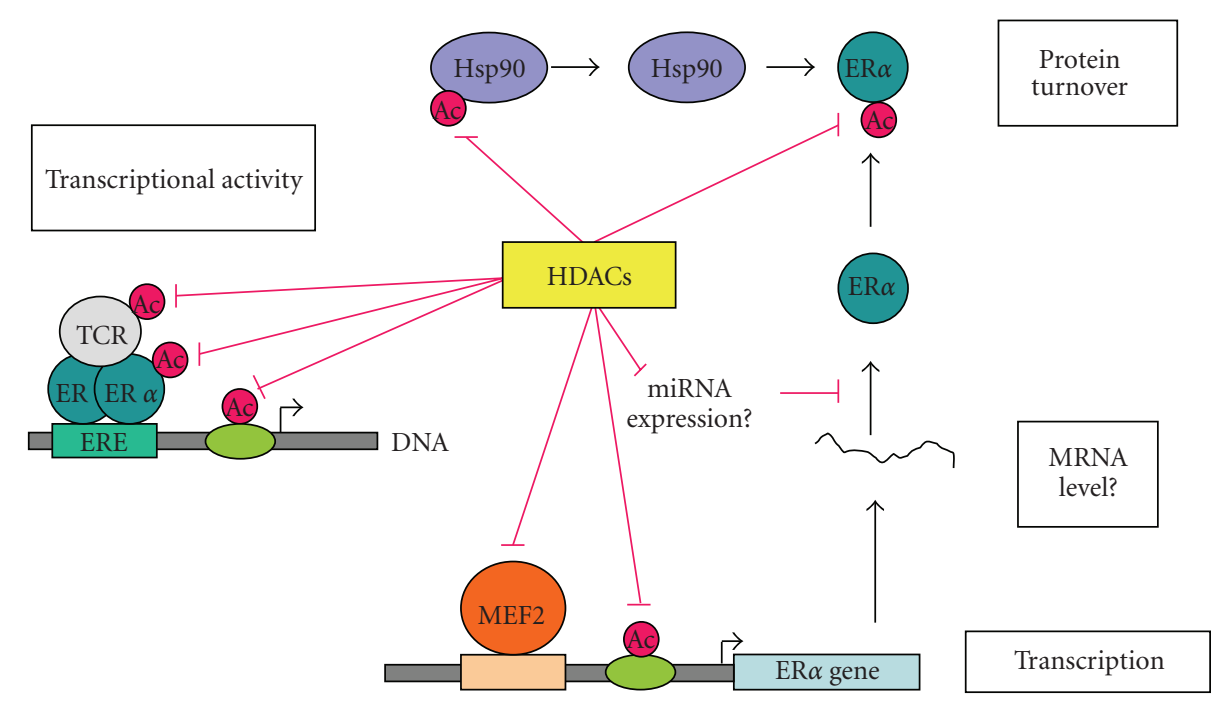

FIGURE 1: HDAC and estrogen signaling. HDACs are involved in estrogen-genomic mechanisms mediated in part through estrogen response element (ERE) targeting. ER $\alpha$ and numerous transcriptional coregulators (TCR) are acetylated proteins (acetyl mark is represented by a red circle) which are substrates for HDAC. By removing acetyl marks, HDAC regulate the transcriptional activity of ER $\alpha$. HDACs also regulate the expression of ER $\alpha$ at the transcriptional level, in part through the control of MEF2 activity. They also modulate the level of ER $\alpha$ mRNA by a mechanism which might involve miRNA expression. Finally, HDACs also regulate ER $\alpha$ stability, and one mechanism appears to involve Hsp90 acetylation.

ER $\alpha$ transcription $[73,103]$. Our unpublished data indicated that the stability of ER $\alpha$ mRNA was not significantly modified in ER $\alpha$-expressing MCF7 cells treated with TSA.

Transcription of the $\mathrm{ER} \alpha$ gene is driven by several different promoters which span over $300 \mathrm{~kb}$ (for a review, see [104]). In MCF7 and Ishikawa cells, levels of transcripts originating from promoters $\mathrm{A}, \mathrm{B}$, and $\mathrm{C}$ were all decreased upon TSA treatment. In endometrial cells, this effect was associated with a reduction of the amount of acetylated $\mathrm{H} 3$ and $\mathrm{H} 4$ on the three promoters confirming the inhibition of their activity [103].

Interestingly, both HDAC5 and HDAC9 (class II enzymes) have been shown to participate in the regulation of the ER $\alpha$ promoter by repressing the activity of MEF2 [87]. A recent study also reported that inhibition of SIRT1 by sirtinol or invalidation of the SIRT1 gene was associated with a decrease of ER $\alpha$ expression in mammary cells which was the consequence of a transcriptional regulation [91]. Finally, several other HDACs could be involved in this negative regulation since a reduction in $\mathrm{ER} \alpha$ expression was observed upon depletion of either HDAC1, HDAC2, or HDAC6 by siRNA in T47D breast cancer cells [82]. In these cases, the levels of regulation remain to be defined.

4.1.2. Regulation of mRNA Stability. A regulation of ER $\alpha$ mRNA expression could also take place at the posttranscriptional level since it has been reported that TSA when administered in combination with 5-Aza2' -deoxycytidine (5azadC or Dacogen) could decrease ER $\alpha$ mRNA stability through altered subcellular localization of the RNA-binding protein, HuR [105]. In addition, several miRNAs (miR206 for instance) have recently been reported to target
ER $\alpha$ mRNA (for a review, see [106]), and some of these miRNAs could be HDI induced and involved in the decreased expression of $\mathrm{ER} \alpha$.

4.1.3. Regulation of Protein Stability. Several data support a regulation at the posttranslational level. Results showing that the MG132 inhibitor relieves the TSA-mediated decrease of $\mathrm{ER} \alpha$ accumulation ([102] and R. Margueron, unpublished observations) provide evidence for a direct or indirect involvement of the proteasome system in this regulation.

At the molecular level, one mechanism could involve the Hsp90 chaperone complex which binds to and maintains $\mathrm{ER} \alpha$ in a ligand-binding conformation [107] and whose inhibition results in ubiquitin-mediated degradation of $\mathrm{ER} \alpha$ by the proteasome [108]. Indeed, the chaperone function of Hsp90 has been shown to depend on HDAC activity, and HDAC6-specific inhibition leads to hyperacetylation of Hsp90, decreases its association with ER $\alpha$, and results in $\mathrm{ER} \alpha$ ubiquitination and depletion [89]. Data reported by $\mathrm{Yi}$ et al. confirmed that inactivation of the heat shock protein-90 (Hsp90) is involved in Vorinostat-induced ER $\alpha$ degradation and that the ubiquitin ligase CHIP (C-terminal Hsc70 interacting protein) enhances Vorinostat-induced ER $\alpha$ degradation [109].

By contrast, a recent paper indicated that TSA-induced acetylation of ER $\alpha$ in T47D cells was accompanied by an increased stability of the ER $\alpha$ protein [110]. Interestingly, in this study, overexpression of p300 also induced acetylation and stability of ER $\alpha$ by blocking ubiquitination.

4.2. Reexpression of ER $\alpha$ in ER-Negative Cells. An interesting aspect concerning $\mathrm{ER} \alpha$ expression and HDAC inhibition 
deals with data obtained in ER $\alpha$-negative human breast cancer cells. The group of N. E. Davidson initially reported that treatment of such cells by TSA [111] or VPA [112] could lead to a dose- and time-dependent reexpression of ER $\alpha$ mRNA. In addition, TSA [113] or Scriptaid (another hydroxamic acid with HDI activity) [114] could potentiate the effect of DNA methyltransferase inhibitors such as 5azadC on the reexpression of the ER $\alpha$ protein.

In ER $\alpha$-negative MDA-MB-231 cells, the silenced ER $\alpha$ promoter has a repressive chromatin structure associated with DNA-methyltransferase 1 (DNMT1), DNMT3b, HDAC1, and H3-K9 methylation [80, 115]. The molecular mechanisms by which HDI reactivated silenced $\mathrm{ER} \alpha$ gene in MDA-MB-231 cells include chromatin structure reorganization: for example, TSA induces acetylated histone $\mathrm{H} 3$ and $\mathrm{H} 4$ but reduces HDAC1 and H3-K9 methylation at the ER $\alpha$ promoter [80]. Chromatin immunoprecipitation analysis showed that binding of TFAP2C to the ER $\alpha$ promoter was blocked in $\mathrm{ER} \alpha$-negative cells, but that treatment with 5azadC/TSA enabled TFAP2C and polymerase II binding [116].

In the ER $\alpha$-negative human breast cancer cell lines MDAMB-231 and MDA-MB-435, treatment with Panobinostat at $100 \mathrm{nM}$ for 24 hours restored ER $\alpha$ mRNA and protein expression without a concomitant demethylation of the ER $\alpha$ promoter CpG island [117]. Importantly, the expression of $\mathrm{ER} \alpha$ mRNA was sustained at least 96 hours after withdrawal of Panobinostat treatment. The same laboratory reported that reexpression of $\mathrm{ER} \alpha$ protein upon treatment with Vorinostat, another pan-HDI, was coupled with loss of EGFR in MDA-MB-231 cells, which overexpress EGFR [118].

4.3. Regulation of ER $\beta$ Expression. Fewer studies have described the effects of HDACs or HDAC inhibition on ER $\beta$ expression in cancer cells. Recent studies reported the upregulation of ER $\beta$ expression in ovarian [119] and prostate cancer cells at the mRNA and protein levels [120].

In breast cancer cells, HDI have been shown to clearly increase ER $\beta$ expression at least at the transcriptional levels in both ER $\alpha$-negative [121] and ER $\alpha$-positive cells [122]. Moreover, treatment with HDI was found to strongly enhance the transcriptional activity of $\operatorname{ER} \beta[121,122]$. According to Jang et al. [121], ER $\beta$ induction upon HDI treatment could be involved in the sensitization of ER $\alpha$ negative breast cancer cells to hormonal therapy (see below).

\section{Roles of HDACs and HDIs in ER Signaling}

In addition to their role in the regulation of ER expression, a large set of data also support a major role of HDACs in the control of transcriptional signaling by estrogens (Table 3 and Figure 1).

5.1. Several Components of the ER Signaling Pathway Are Acetylated Proteins. Several types of posttranslational modifications have been described as targeting nuclear receptor (for a review, see [123]) and could modify several parameters such as DNA-binding activity, interactions with positive or negative transcriptional regulators, and stability or subcellular localization of the protein. It has also been shown that $\operatorname{ER} \alpha$ as other nuclear receptors could be modified at the posttranslational level by addition of acetylated groups on lysine residues $[124,125]$. The group of Pestell initially reported that $\mathrm{ER} \alpha$ was acetylated in vitro by $\mathrm{p} 300$ on two lysine residues located in the hinge region of the protein [126]. Mutation of the two amino acids resulted in an enhancement of hormone sensitivity, suggesting that acetylation normally decreases ligand response. More recently, using a variety of biochemical and cell-based approaches, Kim et al. identified two other lysines within ER $\alpha$ (K266 and K268) as primary targets of NCOA2-dependent p300 acetylation [127]. In this study, acetylation of these residues increased DNA-binding activity of the receptor in gel shift assay and ligand-dependent transactivation in transient transfection experiments. It should be noted that K266/268 are not conserved in ER $\beta$, and until now, acetylation of this nuclear receptor has not been reported. Moreover, the specific deacetylases which remove these marks are still mostly unknown although preliminary data suggested that both the $\mathrm{NAD}^{+}$-dependent SIRT1 enzyme or TSA sensitive $\mathrm{HDAC}$ are able to deacetylate $\mathrm{ER} \alpha$ in vitro.

In addition to nuclear receptors themselves, several other factors involved in estrogen signaling are acetyltransferase substrates. Indeed, several nuclear receptor coregulators such as ACTR/SRC3, SRC-1 and TIF2 [128], PGC1 $\alpha$ [129], RIP140/NRIP1 [130], or HDAC1 [131] are also modified by acetylation, and this highlights the complexity of the effects resulting from the modulation of the acetylation balance in response to HDAC inhibition (see below).

5.2. Direct and Indirect Recruitment of HDACs by ERs. Using the chromatin immunoprecipitation technique (ChIP), the presence of several HDACs has been detected on various ERtarget promoters. For instance, both HDAC1 and HDAC7 are present on the $p S 2$ gene promoter region $[84,90]$. In the presence of partial antiestrogens such as tamoxifen or raloxifen, HDAC2 and HDAC4 [85] or HDAC1 and HDAC3 [81] have been evidenced on the pS2 promoter or on other estrogen target promoters such as the $c-m y c$ or cathepsin $D$ genes.

Several studies have reported different modes of HDAC recruitment by ER $\alpha$. A direct association of HDAC1 with the DNA binding and AF2 domains of ER $\alpha$ has been demonstrated both by GST pull down and coimmunoprecipitation [83]. A more recent study failed to confirm this result, but it described the in vitro interaction with class II HDAC5 and 9 [87]. Finally, HDAC4 was shown to bind the N-terminal $\mathrm{A} / \mathrm{B}$ domain of ER $\alpha[86]$ and, more recently, the physical E2dependent association of HDAC6 with the AF2-domain of $\mathrm{ER} \alpha$ expressed as a fusion with a membrane targeting signal was reported [88].

In addition to direct association with the receptor, HDACs could also be indirectly recruited to target promoters. Indeed, a huge number of ER transcription coregulators which bind the receptor in the presence of agonists (for instance RIP140 [132-134], SHP [135], and REA [136]) or in the presence of antagonists (such as NCoR or SMRT 
$[137,138])$ are able to recruit different HDACs. This indirect recruitment of HDACs belonging to the different classes of enzymes also increases the complexity of the relationship between acetylation and estrogen signaling.

5.3. Role of HDACs in the Control of ER Transcriptional Activity. As already mentioned, HDACs not only regulate ER expression via intricate mechanisms but also participate in the formation of ER transcriptional complexes. Different approaches, based on the modulation of their enzymatic activity or their expression levels, have indeed investigated whether or not they actively participate in the regulation of estrogen transcriptional signaling.

\subsubsection{Effect of HDAC Inhibitors on ER Transcriptional Activity.} Using MCF-7 or HeLa cells transfected with an EREcontaining luciferase reporter plasmid, we showed that inhibition of HDAC activity increased transactivation of both $\operatorname{ER} \alpha$ and $\operatorname{ER} \beta$ in the presence of agonist ligands [122]. In ER $\alpha$-expressing cells, HDAC inhibitors also abolished the transrepression ability of partial antiestrogens and increased their agonist activity through a mechanism which requires the reduction of ER $\alpha$ expression [100]. This effect was not obtained with class II selective inhibitors [74].

5.3.2. Class I HDAC. Very few data are available concerning the role of class I HDACs in the control of ER activity. Kawai et al. suggested that HDAC1 overexpression in 293T cells suppresses the E2-dependent transcriptional activity of ER $\alpha$ [83]. However, it is difficult to ascertain that this effect was indeed due to a modulation of receptor transactivation and not a simple reflect of a strong decrease in receptor levels. Using a Knockdown strategy, it has been reported more recently that selective depletion of HDAC2 in T47D cells resulted in a decrease in PR levels but it is unclear whether this is due to a modulation of $\mathrm{ER} \alpha$ activity [82].

5.3.3. Class II HDAC. Class II HDACs have also been demonstrated to act as important modulators of $\mathrm{ER} \alpha$ activity. A recent paper from the Olson's laboratory has demonstrated a role for HDAC5 and 9 in cardioprotection mediated by ER $\alpha$ [87]. Upregulation of $\mathrm{ER} \alpha$ signaling in female mice deleted for either HDAC5 or -9 dramatically diminishes cardiac dysfunction following myocardial infarction. This cardiac protection appears to be due, at least in part, to the induction of neoangiogenesis in the infarcted region via upregulation of the ER target gene Vascular Endothelial Growth Factor (VEGF). These findings reveal a key role for MEF2 and class II HDACs in the regulation of cardiac ER signaling and the mechanisms underlying the cardioprotective effects of estrogen. Accordingly, van Rooij et al. showed that HDAC5 and HDAC9 repressed estrogen-dependent transcriptional activation by $\mathrm{ER} \alpha$.

Another class II HDAC, HDAC7, seems to play a unique role in E2-dependent repression of gene expression [90]. Indeed, in transient transfection experiments, increasing concentrations of HDAC7 inhibited ER $\alpha$ activity in a dosedependent manner although the catalytic activity of HDAC7 did not appear to be required. More interestingly, knockdown of HDAC7 using siRNA resulted in complete loss of E2 repression of different target genes such as RPRM, CXCR4, or NEDD9.

HDAC4 has also been shown to regulate transactivation by $\mathrm{ER} \alpha$ in the presence of either estradiol or antiestrogens such as tamoxifen or raloxifen [86]. Overexpression or silencing of HDAC4 impacted (negatively or positively) ER $\alpha$ activity in a cell type-specific manner.

Finally, HDAC6 may also participates in rapid action of estrogens (the so-called nongenomic action of ER), since it has been proposed that upon estrogen stimulation, a complex containing ER $\alpha$ and HDAC6 is rapidly translocated at the membrane, where HDAC6 could functionally interact with the microtubule network and cause tubulin deacetylation [88]. However, analysis of E2-induced tubulin deacetylation remains to be analyzed in HDAC6 knockdown or knockout models.

5.3.4. Class III HDAC. A single study has investigated whether class III HDACs play a role in the regulation of $\mathrm{ER} \alpha$ activity [91]. This work demonstrated that sirtinol, an inhibitor of the SIRT1 deacetylase activity, inhibited estrogen-dependent gene transcription in different breast cancer cell lines. This observation could be related to previous data showing that the loss of SIRT1 expression in female mice is associated with a defect in mammary gland development [139].

\section{Effects of HDIs on HT Response}

\subsection{In Vitro Experiments}

6.1.1. ER $\alpha$-Positive Breast Tumors. As discussed briefly in Section 3, several HDIs have been shown to reverse acquired hormone resistance in ER $\alpha$-positive breast cancer cells lines. For example, Hirokawa et al. showed that treatment of tamoxifen sensitive and insensitive MCF-7 cells with depsipeptide not only inhibited tumor cells proliferation in vitro and in vivo but also abrogated tamoxifen-resistance. These data suggest that HDIs could be useful for the treatment of breast cancers which become resistant to currently used estrogen antagonists such as tamoxifen [97]. Moreover, Hodges-Gallagher et al. suggested that this resensitization upon HDI, was not limited to tamoxifen, but could also be observed with aromatase inhibitors [140]. The mechanisms by which HDIs may reverse acquired hormone resistance in ER $\alpha$-positive breast tumor cells are probably complex and may involve different mechanisms according to tamoxifen or antiaromatase treatments. For instance, inhibition of HDAC enzymatic activity modulates $\mathrm{ER} \alpha$ and $\mathrm{ER} \beta$ expression and may control the relative agonist activity of partial antiestrogens (see above) [100]. Moreover, HDIs block the activation of PAK1 [97], a growth factor pathway, which may contribute to tamoxifen resistance [141]. In addition, De Los Santos et al. showed that a combination of Vorinostat and fulvestrant (a pure steroidal anti-estrogen also known as ICI 182.780) was more potent than fulvestrant alone 
to regulate the expression of cell cycle proteins, to induce downregulation of $E R \alpha$, and to decrease the transcription of $\mathrm{ER} \alpha$ target genes in MCF-7 breast cancer cells [75].

To our knowledge, no preclinical study has been published evaluating the effects of a treatment combining HDI and HTs (tamoxifen or aromatase inhibitor) on the delay of endocrine acquired resistance in ER $\alpha$-positive breast cancer cells or in xenografts.

6.1.2. ER $\alpha$-Negative Breast Tumors. As stated in Section 1, HTs are ineffective in ER $\alpha$-negative breast carcinoma. Preclinical studies have shown that $\mathrm{ER} \alpha$ repression in these tumors may be due to epigenetic modifications. The discovery of HDACs recruitment in $\mathrm{ER} \alpha$ gene promoter provides a rationale for inhibiting HDACs activity to release ER $\alpha$ transcriptional repression as a potential therapeutic strategy (see Section 4). Several laboratories have reported that HDIs could reverse hormone resistance in human $\mathrm{ER} \alpha$-negative breast cancer cells. The combination of TSA and 5-azadC, a DNMT inhibitor, restored sensitivity to tamoxifen in MDAMB 235 human breast cell lines and in nude mice. This effect was due to the reexpression of a functional ER $\alpha$ and the level of tamoxifen growth suppression paralleled that of ER $\alpha$ reexpression [98]. Similarly, restoration of ER $\alpha$ expression by the pan HDI Panobinostat in MDAMB 231 cells enhanced sensitivity to 4-hydroxy-tamoxifen (an active metabolite of tamoxifen) [117]. So, reexpression of ER $\alpha$ might at least in part mediate the antiproliferative effect of tamoxifen, although other mechanisms are likely to be involved. For instance, Jang et al. observed that pretreatment of ER $\alpha$-negative MDA-MB 231 and Hs578T breast cancer cells with TSA alone could restore response to tamoxifen whereas no apparent ER $\alpha$ could be detected in the treated cells. The mechanism involved might be linked to the upregulation of ER $\beta$ expression [121]. Other mechanisms may involve modulation of growth signaling pathways. Zhou et al. indeed showed that Panobinostat allowed a decrease in EGFR expression together with the suppression of EGF-initiated signaling pathways involved in the loss of tamoxifen antiestrogenic effect including phosphorylated PAK1, p38MAPK, and AKT [142]. Treatment of $\mathrm{ER} \alpha$-negative and hormone resistant human breast cancer cells MDA-MB 231 or xenografts with the HDI SNDX275 (MS275 or Entinostat) led to an upregulation of ER $\alpha$ and aromatase expression. Importantly for clinical perspectives, these up regulations resulted in a sensitization of MDA-MB 231 cells and xenografts to a treatment with an aromatase inhibitor (Letrozole). The same authors reported inhibition of growth, cell migration, and formation of micrometastasis by treatment with Entinostat plus letrozole (Sabnis et al., communication at the San Antonio Breast Cancer Symposium 2009). Altogether, these results provide the basis of therapies combining tamoxifen (or aromatase inhibitors) and HDIs for the treatment of hormone refractory ER $\alpha$ negative breast cancer and open a new perspective for the management of $\mathrm{ER} \alpha$-negative breast cancer.

6.2. Clinical Trials. Several HDIs have been used in clinical trials for the treatment of hematological malignancies (with great success in most studies) and for solid tumors although with less impressive clinical efficacy. Concerning breast cancer, the HDIs Vorinostat, Panobinostat, and Entinostat are currently being tested in patients with advanced and/or metastatic disease. The most common adverse events of HDI treatment include fatigue, nausea, diarrhea, thrombocytopenia, and lymphopenia $[17,18]$. In metastatic breast cancers, HDIs have limited efficacy as single agents. For example, a phase II study evaluating Vorinostat alone was stopped early due to the absence of objective responses [143]. A phase II study evaluating the efficacy of Panobinostat alone in HER2-negative women with locally recurrence or metastatic breast cancer is still ongoing (NCI clinical trial protocol NCT00777049; see http://www.cancer.gov/).

As stated above, HDIs as single agents have shown limited activity in patients with solid tumor malignancies, thus prompting clinicians to use these compounds in combination with other therapies acting on other targets than HDACs. Such drug combinations interfering with both HDACs and growth factor pathways (HER2, EGFR, BCR-ABL, etc.) have already shown promising anticancer effects in vitro [144-146]. Moreover, studies combining an HDI with chemotherapy (Munster et al., communication at the San Antonio Breast Cancer Symposium 2009) or trastuzumab, an HER2 monoclonal antibody, (NCI clinical trial NCT00567879) are ongoing. Preliminary results, in heavily pretreated women who had either relapsed or progressed during trastuzumab combined therapies proved to be promising: Vorinostat or Panobinostat were indeed shown to reverse trastuzumab resistance.

Since there is a good rationale for combining HDI with HTs, several trials involving the combination of a panor a selective HDI and an HT (tamoxifen, or aromatase inhibitor) are ongoing (see Table 4). At the SABCS 2009, Munster et al. reported preliminary results of a phase II study, combining Vorinostat $(400 \mathrm{mg}$ daily for 21 days of 28 days) and tamoxifen ( $20 \mathrm{mg}$ daily), in women with ERpositive metastatic breast cancers whose tumor progressed under aromatase inhibitors treatment. Moreover, patients could have received up to 3 chemotherapy regimens for metastatic disease. In the first 42 patients enrolled in this trial, 34 were assessable for efficacy to the date of the report: $7(21 \%)$ had an objective response, and $4(12 \%)$ had stable disease for $\geq 6$ months. These results are encouraging if one considers that the expected response rate for tamoxifen alone at this stage of disease is less than $10 \%$ and that the trial of Luu et al., evaluating Vorinostat alone in metastatic breast carcinoma reported no objective responses [143].

Moreover, a preliminary phase II data suggest that Entinostat, a class I selective HDI, may resensitize invasive ER-positive breast cancer patients progressing under aromatase inhibitors although $80 \%$ of these patients had already received tamoxifen (Yardley et al., communication at the San Antonio Breast Cancer Symposium 2009). In metastatic breast carcinoma, additional trials involving the combination of an HDI including Vorinostat and Panobinostat with aromatase inhibitors are underway. 
TABLE 4: Clinical trials combining HDI and HT in advanced/metastatic ER-positive breast carcinoma.

\begin{tabular}{|c|c|c|c|c|c|}
\hline HDI & $\mathrm{HT}$ & Phase & Patients & Preliminary results & Reference \\
\hline $\begin{array}{l}\text { Vorinostat (SAHA) } \\
200 \mathrm{mg} \text { twice daily } \\
14 \mathrm{~d} / 21\end{array}$ & Tam & II & AI resistant $\mathrm{HR}+$ & $\begin{array}{c}34 \text { patients evaluated } \\
21 \% \text { OR } \\
12 \% \mathrm{SD}\end{array}$ & $\begin{array}{l}\text { Munster et al. } \\
\text { Poster \# } 6100 \\
\text { SABCS } 2009\end{array}$ \\
\hline $\begin{array}{l}\text { Entinostat } \\
\text { (SNDX275) } \\
5 \text { mg weekly }\end{array}$ & $\begin{array}{c}\text { AI } \\
\text { (Exemestane) }\end{array}$ & II & AI resistant $\mathrm{HR}+$ & $\begin{array}{c}10 \text { patients with }>2 \\
\text { cycles } \\
\mathrm{CB}>6 \text { months }(1 \text { case }) \\
\mathrm{CB}>5 \text { months }(2 \text { cases })\end{array}$ & $\begin{array}{l}\text { NCI clinical trial } \\
\text { NCT00676663 } \\
\text { Yardley et al. } \\
\text { Poster \# } 6111 \\
\text { SABCS } 2009\end{array}$ \\
\hline $\begin{array}{l}\text { Vorinostat (SAHA) } \\
200 \mathrm{mg} \text { twice daily } \\
14 \mathrm{~d} / 21\end{array}$ & $\begin{array}{c}\mathrm{AI} \\
\text { (anastrozole } \\
\text { letrozole, OR } \\
\text { exemestane) }\end{array}$ & II & AI resistant & Ongoing & $\begin{array}{l}\text { NCI clinical trial } \\
\text { NCT01153672 } \\
\text { Linden et al. }\end{array}$ \\
\hline $\begin{array}{l}\text { Panobinostat } \\
\text { (LBH589) once daily } \\
\text { on days 1, 3, } 5 \text { during } \\
28 \mathrm{~d}\end{array}$ & $\begin{array}{c}\text { AI } \\
\text { (Letrozole) }\end{array}$ & $\mathrm{I} / \mathrm{II}$ & $\begin{array}{l}\mathrm{HR}-/+(\text { phase I) } \\
\text { triple-negative } \\
\text { disease (phase II) }\end{array}$ & Ongoing & $\begin{array}{l}\text { NCI clinical trial } \\
\text { NCT01105312 Tan } \\
\text { et al. }\end{array}$ \\
\hline Vorinostat (SAHA) & Tam & II & $\begin{array}{l}\text { Stage I-III } \\
\text { (treatment for } 2 \\
\text { weeks before } \\
\text { surgery) }\end{array}$ & Ongoing & $\begin{array}{l}\text { NCI clinical trial } \\
\text { NCT01194427 } \\
\text { Stearns et al. }\end{array}$ \\
\hline
\end{tabular}

AI: aromatase inhibitor. OR: objective response. SD: stable disease. CB: clinical benefice. HR: hormone receptor. SABCS: San Antonio Breast Cancer Symposium 2009.

\section{Perspectives and Conclusions}

In conclusion, analysis of the links between ERs and HDACs underline multiple and intricate levels of interactions. Such complexity is reflected in breast tumorigenesis as HDI have opposite effects on ER $\alpha$ expression in ER-positive and ERnegative breast tumor cells. Several important questions remain to be answered in order to further appreciate these transcriptional and cellular crosstalks: what are the roles of the different HDAC isoforms? Do HDAC regulate ER signaling independently of their catalytic activity? Are sirtuins key players in these crosstalks? Do HDACs regulate miRNA which target ER signaling? What is the exact role of HDACs in hormone resistant breast tumors?

Despite these open questions, HDI in combination with chemotherapies or hormonal therapies led to promising results in the context of hormone-resistant breast cancers, and several clinical trials are still ongoing in this field. Further studies are needed to define the best combinations of HDI therapies for the most aggressive breast tumors and to better understand how they impact hormone-resistant breast cancers.

Moreover, as stated in this paper, much work is being done today to define biomarkers that would identify which tumors will better respond to HDI-combined treatments. In the field of breast cancer, it will certainly be important to define biomarkers for the reexpression of ER $\alpha$ in ER-negative tumors along with predictive biomarkers of anti-estrogen sensitivity in hormone resistant tumors in response to HDI treatments. Finally, few data have been performed on triple negative breast tumors, which represent one of the most aggressive groups of breast cancers or in the familial forms of
BRCA1 mutated tumors. The role of HDACs and the impact of HDIs in these particular groups could possibly open new therapeutic strategies.

\section{References}

[1] "Tamoxifen for early breast cancer: an overview of the randomised trials. Early Breast Cancer Trialists' Collaborative Group," Lancet, pp. 1451-1467, 1998.

[2] W. L. McGuire, K. B. Horwitz, O. H. Pearson, and A. Segaloff, "Current status of estrogen and progesterone receptors in breast cancer," Cancer, vol. 39, no. 6, pp. 2934-2947, 1977.

[3] V. J. Bardou, G. Arpino, R. M. Elledge, C. K. Osborne, and G. M. Clark, "Progesterone receptor status significantly improves outcome prediction over estrogen receptor status alone for adjuvant endocrine therapy in two large breast cancer databases," Journal of Clinical Oncology, vol. 21, no. 10, pp. 1973-1979, 2003.

[4] S. Massarweh and R. Schiff, "Unraveling the mechanisms of endocrine resistance in breast cancer: new therapeutic opportunities," Clinical Cancer Research, vol. 13, no. 7, pp. 1950-1954, 2007.

[5] R. B. Riggins, R. S. Schrecengost, M. S. Guerrero, and A. H. Bouton, "Pathways to tamoxifen resistance," Cancer Letters, vol. 256, no. 1, pp. 1-24, 2007.

[6] J. M. Hoskins, L. A. Carey, and H. L. McLeod, "CYP2D6 and tamoxifen: DNA matters in breast cancer," Nature Reviews Cancer, vol. 9, no. 8, pp. 576-586, 2009.

[7] N. Heldring, A. Pike, S. Andersson et al., "Estrogen receptors: how do they signal and what are their targets," Physiological Reviews, vol. 87, no. 3, pp. 905-931, 2007.

[8] X. J. Yang and E. Seto, "HATs and HDACs: from structure, function and regulation to novel strategies for therapy and prevention," Oncogene, vol. 26, no. 37, pp. 5310-5318, 2007. 
[9] X. J. Yang and E. Seto, "The Rpd3/Hda1 family of lysine deacetylases: from bacteria and yeast to mice and men," Nature Reviews Molecular Cell Biology, vol. 9, no. 3, pp. 206218, 2008.

[10] A. Vannini, C. Volpari, P. Gallinari, P. Jones, C. Steinkühler, and S. Di Marco, "Substrate binding to histone deacetylases as shown by the crystal structure of the HDAC8-substrate complex," EMBO Reports, vol. 8, no. 9, pp. 879-884, 2007.

[11] A. Schuetz, J. Min, A. Allali-Hassani et al., "Human HDAC7 harbors a class IIa histone deacetylase-specific zinc binding motif and cryptic deacetylase activity," Journal of Biological Chemistry, vol. 283, no. 17, pp. 11355-11363, 2008.

[12] R. Ficner, "Novel structural insights into class I and II histone deacetylases," Current Topics in Medicinal Chemistry, vol. 9, no. 3, pp. 235-240, 2009.

[13] M. Haberland, R. L. Montgomery, and E. N. Olson, "The many roles of histone deacetylases in development and physiology: implications for disease and therapy," Nature Reviews Genetics, vol. 10, no. 1, pp. 32-42, 2009.

[14] O. Witt, H. E. Deubzer, T. Milde, and I. Oehme, "HDAC family: what are the cancer relevant targets?" Cancer Letters, vol. 277 , no. 1 , pp. 8-21, 2009.

[15] W. Weichert, "HDAC expression and clinical prognosis in human malignancies," Cancer Letters, vol. 280, no. 2, pp. 168 $176,2009$.

[16] P. A. Marks and R. Breslow, "Dimethyl sulfoxide to vorinostat: development of this histone deacetylase inhibitor as an anticancer drug," Nature Biotechnology, vol. 25, no. 1, pp. 8490, 2007.

[17] J. Tan, S. Cang, Y. Ma, R. L. Petrillo, and D. Liu, "Novel histone deacetylase inhibitors in clinical trials as anti-cancer agents," Journal of Hematology and Oncology, vol. 3, article no. 5, 2010.

[18] S. Cang, Y. Ma, and D. Liu, "New clinical developments in histone deacetylase inhibitors for epigenetic therapy of cancer," Journal of Hematology and Oncology, vol. 2, article no. 22, 2009.

[19] T. Liu, S. Kuljaca, A. Tee, and G. M. Marshall, "Histone deacetylase inhibitors: multifunctional anticancer agents," Cancer Treatment Reviews, vol. 32, no. 3, pp. 157-165, 2006.

[20] W. S. Xu, R. B. Parmigiani, and P. A. Marks, "Histone deacetylase inhibitors: molecular mechanisms of action," Oncogene, vol. 26, no. 37, pp. 5541-5552, 2007.

[21] J. E. Bolden, M. J. Peart, and R. W. Johnstone, "Anticancer activities of histone deacetylase inhibitors," Nature Reviews Drug Discovery, vol. 5, no. 9, pp. 769-784, 2006.

[22] S. Minucci and P. G. Pelicci, "Histone deacetylase inhibitors and the promise of epigenetic (and more) treatments for cancer," Nature Reviews Cancer, vol. 6, no. 1, pp. 38-51, 2006.

[23] S. Balasubramanian, E. Verner, and J. J. Buggy, "Isoformspecific histone deacetylase inhibitors: the next step?" Cancer Letters, vol. 280, no. 2, pp. 211-221, 2009.

[24] L. Stimson and N. B. La Thangue, "Biomarkers for predicting clinical responses to HDAC inhibitors," Cancer Letters, vol. 280, no. 2, pp. 177-183, 2009.

[25] P. N. Munster, D. Marchion, S. Thomas et al., "Phase I trial of vorinostat and doxorubicin in solid tumours: histone deacetylase 2 expression as a predictive marker," British Journal of Cancer, vol. 101, no. 7, pp. 1044-1050, 2009.

[26] L. Ellis, Y. Pan, G. K. Smyth et al., "Histone deacetylase inhibitor panobinostat induces clinical responses with associated alterations in gene expression profiles in cutaneous Tcell lymphoma," Clinical Cancer Research, vol. 14, no. 14, pp. 4500-4510, 2008.
[27] O. Khan, S. Fotheringham, V. Wood et al., "HR23B is a biomarker for tumor sensitivity to HDAC inhibitor-based therapy," Proceedings of the National Academy of Sciences of the United States of America, vol. 107, no. 14, pp. 6532-6537, 2010.

[28] J. Suzuki, Y. Y. Chen, G. K. Scott et al., "Protein acetylation and histone deacetylase expression associated with malignant breast cancer progression," Clinical Cancer Research, vol. 15, no. 9, pp. 3163-3171, 2009.

[29] C. A. Krusche, P. Wulfing, C. Kersting et al., "Histone deacetylase-1 and -3 protein expression in human breast cancer: a tissue microarray analysis," Breast Cancer Research and Treatment, vol. 90, no. 1, pp. 15-23, 2005.

[30] Z. Zhang, H. Yamashita, T. Toyama et al., "Quantitation of HDAC1 mRNA expression in invasive carcinoma of the breast," Breast Cancer Research and Treatment, vol. 94, no. 1, pp. 11-16, 2005.

[31] X. Hu, H. M. Stern, L. Ge et al., "Genetic alterations and oncogenic pathways associated with breast cancer subtypes," Molecular Cancer Research, vol. 7, no. 4, pp. 511-522, 2009.

[32] C. Sotiriou, P. Wirapati, S. Loi et al., "Gene expression profiling in breast cancer: understanding the molecular basis of histologic grade to improve prognosis," Journal of the National Cancer Institute, vol. 98, no. 4, pp. 262-272, 2006.

[33] L. H. Saal, P. Johansson, K. Holm et al., "Poor prognosis in carcinoma is associated with a gene expression signature of aberrant PTEN tumor suppressor pathway activity," Proceedings of the National Academy of Sciences of the United States of America, vol. 104, no. 18, pp. 7564-7569, 2007.

[34] A. H. Bild, G. Yao, J. T. Chang et al., "Oncogenic pathway signatures in human cancers as a guide to targeted therapies," Nature, vol. 439, no. 7074, pp. 353-357, 2006.

[35] K. Chin, S. DeVries, J. Fridlyand et al., "Genomic and transcriptional aberrations linked to breast cancer pathophysiologies," Cancer Cell, vol. 10, no. 6, pp. 529-541, 2006.

[36] S. Gruvberger, M. Ringner, Y. Chen et al., "Estrogen receptor status in breast cancer is associated with remarkably distinct gene expression patterns," Cancer Research, vol. 61, no. 16, pp. 5979-5984, 2001.

[37] A. V. Ivshina, J. George, O. Senko et al., "Genetic reclassification of histologic grade delineates new clinical subtypes of breast cancer," Cancer Research, vol. 66, no. 21, pp. 1029210301, 2006.

[38] A. J. Minn, G. P. Gupta, P. M. Siegel et al., "Genes that mediate breast cancer metastasis to lung," Nature, vol. 436, no. 7050, pp. 518-524, 2005.

[39] M. J. Van De Vijver, Y. D. He, L. J. Van 'T Veer et al., “A gene-expression signature as a predictor of survival in breast cancer," New England Journal of Medicine, vol. 347, no. 25, pp. 1999-2009, 2002.

[40] Y. Wang, J. G. M. Klijn, Y. Zhang et al., "Gene-expression profiles to predict distant metastasis of lymph-node-negative primary breast cancer," Lancet, vol. 365, no. 9460, pp. 671679, 2005.

[41] M. West, C. Blanchette, H. Dressman et al., "Predicting the clinical status of human breast cancer by using gene expression profiles," Proceedings of the National Academy of Sciences of the United States of America, vol. 98, no. 20, pp. 11462-11467, 2001.

[42] K. Yu, K. Ganesan, L. D. Miller, and P. Tan, "A modular analysis of breast cancer reveals a novel low-grade molecular signature in estrogen receptor-positive tumors," Clinical Cancer Research, vol. 12, no. 11, pp. 3288-3296, 2006. 
[43] B. J. Boersma, M. Reimers, M. Yi et al., "A stromal gene signature associated with inflammatory breast cancer," International Journal of Cancer, vol. 122, no. 6, pp. 13241332, 2008.

[44] I. Hedenfalk, D. Duggan, Y. Chen et al., "Gene-expression profiles in hereditary breast cancer," New England Journal of Medicine, vol. 344, no. 8, pp. 539-548, 2001.

[45] X. Lu, X. Lu, Z. C. Wang, J. D. Iglehart, X. Zhang, and A. L. Richardson, "Predicting features of breast cancer with gene expression patterns," Breast Cancer Research and Treatment, vol. 108, no. 2, pp. 191-201, 2008.

[46] C. M. Perou, T. Sørile, M. B. Eisen et al., "Molecular portraits of human breast tumours," Nature, vol. 406, no. 6797, pp. 747-752, 2000.

[47] A. L. Richardson, Z. C. Wang, A. De Nicolo et al., "X chromosomal abnormalities in basal-like human breast cancer," Cancer Cell, vol. 9, no. 2, pp. 121-132, 2006.

[48] T. Sorlie, C. M. Perou, R. Tibshirani et al., "Gene expression patterns of breast carcinomas distinguish tumor subclasses with clinical implications," Proceedings of the National Academy of Sciences of the United States of America, vol. 98, no. 19, pp. 10869-10874, 2001.

[49] J. R. Pollack, T. Sorlie, C. M. Perou et al., "Microarray analysis reveals a major direct role of DNA copy number alteration in the transcriptional program of human breast tumors," Proceedings of the National Academy of Sciences of the United States of America, vol. 99, no. 20, pp. 12963-12968, 2002.

[50] T. Sorlie, R. Tibshirani, J. Parker et al., "Repeated observation of breast tumor subtypes in independent gene expression data sets," Proceedings of the National Academy of Sciences of the United States of America, vol. 100, no. 14, pp. 8418-8423, 2003.

[51] C. Desmedt, F. Piette, S. Loi et al., "Strong time dependence of the 76-gene prognostic signature for node-negative breast cancer patients in the TRANSBIG multicenter independent validation series," Clinical Cancer Research, vol. 13, no. 11, pp. 3207-3214, 2007.

[52] C. Ginestier, N. Cervera, P. Finetti et al., "Prognosis and gene expression profiling of 20q13-amplified breast cancers," Clinical Cancer Research, vol. 12, no. 15, pp. 4533-4544, 2006.

[53] K. R. Hess, K. Anderson, W. F. Symmans et al., "Pharmacogenomic predictor of sensitivity to preoperative chemotherapy with paclitaxel and fluorouracil, doxorubicin, and cyclophosphamide in breast cancer," Journal of Clinical Oncology, vol. 24, no. 26, pp. 4236-4244, 2006.

[54] E. Huang, S. H. Cheng, H. Dressman et al., "Gene expression predictors of breast cancer outcomes," Lancet, vol. 361, no. 9369, pp. 1590-1596, 2003.

[55] P. M. Haverty, J. Fridlyand, L. Li et al., "High-resolution genomic and expression analyses of copy number alterations in breast tumors," Genes Chromosomes and Cancer, vol. 47, no. 6, pp. 530-542, 2008.

[56] P. K. Julka, R. T. Chacko, S. Nag et al., "A phase II study of sequential neoadjuvant gemcitabine plus doxorubicin followed by gemcitabine plus cisplatin in patients with operable breast cancer: prediction of response using molecular profiling," British Journal of Cancer, vol. 98, no. 8, pp. 13271335, 2008.

[57] C. Sotiriou, S. Y. Neo, L. M. McShane et al., "Breast cancer classification and prognosis based on gene expression profiles from a population-based study," Proceedings of the National Academy of Sciences of the United States of America, vol. 100, no. 18, pp. 10393-10398, 2003.
[58] H. Zhao, A. Langerod, Y. Ji et al., "Different gene expression patterns in invasive lobular and ductal carcinomas of the breast," Molecular Biology of the Cell, vol. 15, no. 6, pp. 25232536, 2004.

[59] Z. Zhang, H. Yamashita, T. Toyama et al., "HDAC6 expression is correlated with better survival in breast cancer," Clinical Cancer Research, vol. 10, no. 20, pp. 6962-6968, 2004.

[60] S. Saji, M. Kawakami, S. I. Hayashi et al., "Significance of HDAC6 regulation via estrogen signaling for cell motility and prognosis in estrogen receptor-positive breast cancer," Oncogene, vol. 24, no. 28, pp. 4531-4539, 2005.

[61] S. F. Chin, A. E. Teschendorff, J. C. Marioni et al., "Highresolution aCGH and expression profiling identifies a novel genomic subtype of ER negative breast cancer," Genome Biology, vol. 8, no. 10, article no. R215, 2007.

[62] Y. Nikolsky, E. Sviridov, J. Yao et al., "Genome-wide functional synergy between amplified and mutated genes in human breast cancer," Cancer Research, vol. 68, no. 22, pp. 9532-9540, 2008.

[63] A. Inoue, N. Yoshida, Y. Omoto et al., "Development of cDNA microarray for expression profiling of estrogenresponsive genes," Journal of Molecular Endocrinology, vol. 29, no. 2, pp. 175-192, 2002.

[64] Y. S. Lee, K. H. Lim, X. Guo et al., "The cytoplasmic deacetylase HDAC6 is required for efficient oncogenic tumorigenesis," Cancer Research, vol. 68, no. 18, pp. 75617569, 2008.

[65] N. Yoshida, Y. Omoto, A. Inoue et al., "Prediction of prognosis of estrogen receptor-positive breast cancer with combination of selected estrogen-regulated genes," Cancer Science, vol. 95, no. 6, pp. 496-502, 2004.

[66] C. L. Hanigan, M. van Engeland, A. P. De Bruine et al., "An inactivating mutation in HDAC2 leads to dysregulation of apoptosis mediated by APAF1," Gastroenterology, vol. 135, no. 5, pp. 1654-1664, 2008.

[67] T. Davis, C. Kennedy, Y. E. Chiew, C. L. Clarke, and A. Defazio, "Histone deacetylase inhibitors decrease proliferation and modulate cell cycle gene expression in normal mammary epithelial cells," Clinical Cancer Research, vol. 6, no. 11, pp. 4334-4342, 2000.

[68] D. M. Vigushin, S. Ali, P. E. Pace et al., "Trichostatin A is a histone deacetylase inhibitor with potent antitumor activity against breast cancer in vivo," Clinical Cancer Research, vol. 7, no. 4, pp. 971-976, 2001.

[69] R. Margueron, V. Duong, A. Castet, and V. Cavailles, "Histone deacetylase inhibition and estrogen signalling in human breast cancer cells," Biochemical Pharmacology, vol. 68, no. 6, pp. 1239-1246, 2004.

[70] R. Margueron, A. Licznar, G. Lazennec, F. Vignon, and V. Cavailles, "Oestrogen receptor $\alpha$ increases p21/C gene expression and the antiproliferative activity of histone deacetylase inhibitors in human breast cancer cells," Journal of Endocrinology, vol. 179, no. 1, pp. 41-53, 2003.

[71] J. P. Alao, A. V. Stavropoulou, E. W. F. Lam, R. C. Coombes, and D. M. Vigushin, "Histone deacetylase inhibitor, Trichostatin A induces ubiquitin-dependent cyclin D1 degradation in MCF-7 breast cancer cells," Molecular Cancer, vol. 5, article no. 8, 2006.

[72] M. Ocker and R. Schneider-Stock, "Histone deacetylase

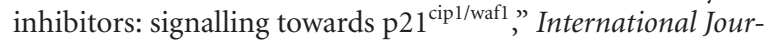
nal of Biochemistry and Cell Biology, vol. 39, no. 7-8, pp. 1367-1374, 2007. 
[73] J. P. Alao, E. W.-F. Lam, S. Ali et al., "Histone deacetylase inhibitor trichostatin A represses estrogen receptor $\alpha$ dependent transcription and promotes proteasomal degradation of cyclin D1 in human breast carcinoma cell lines," Clinical Cancer Research, vol. 10, no. 23, pp. 8094-8104, 2004.

[74] V. Duong, C. Bret, L. Altucci et al., "Specific activity of class II histone deacetylases in human breast cancer cells," Molecular Cancer Research, vol. 6, no. 12, pp. 1908-1919, 2008.

[75] M. De Los Santos, O. Martinez-Iglesias, and A. Aranda, "Anti-estrogenic actions of histone deacetylase inhibitors in MCF-7 breast cancer cells," Endocrine-Related Cancer, vol. 14, no. 4, pp. 1021-1028, 2007.

[76] L. Travaglini, L. Vian, M. Billi, F. Grignani, and C. Nervi, "Epigenetic reprogramming of breast cancer cells by valproic acid occurs regardless of estrogen receptor status," International Journal of Biochemistry and Cell Biology, vol. 41, no. 1, pp. 225-234, 2009.

[77] L. Fuino, P. Bali, S. Wittmann et al., "Histone deacetylase inhibitor LAQ824 down-regulates Her-2 and sensitizes human breast cancer cells to trastuzumab, taxotere, gemcitabine, and epothilone B," Molecular Cancer Therapeutics, vol. 2, no. 10, pp. 971-984, 2003.

[78] V. Chopin, R. A. Toillon, N. Jouy, and X. Le Bourhis, "P21 is dispensable for $\mathrm{G} 1$ arrest, but indispensable for apoptosis induced by sodium butyrate in MCF-7 breast cancer cells," Oncogene, vol. 23, no. 1, pp. 21-29, 2004.

[79] P. Bali, M. Pranpat, R. Swaby et al., "Activity of suberoylanilide hydroxamic acid against human breast cancer cells with amplification of Her-2," Clinical Cancer Research, vol. 11, no. 17, pp. 6382-6389, 2005.

[80] D. Sharma, J. Blum, X. Yang, N. Beaulieu, A. R. Macleod, and N. E. Davidson, "Release of methyl CpG binding proteins and histone deacetylase 1 from the estrogen receptor $\alpha$ (ER) promoter upon reactivation in ER-negative human breast cancer cells," Molecular Endocrinology, vol. 19, no. 7, pp. 1740-1751, 2005.

[81] X. F. Liu and M. K. Bagchi, "Recruitment of distinct chromatin-modifying complexes by tamoxifen-complexed estrogen receptor at natural target gene promoters in vivo," Journal of Biological Chemistry, vol. 279, no. 15, pp. 1505015058, 2004.

[82] E. Biçaku, D. C. Marchion, M. L. Schmitt, and P. N. Munster, "Selective inhibition of histone deacetylase 2 silences progesterone receptor-mediated signaling," Cancer Research, vol. 68, no. 5, pp. 1513-1519, 2008.

[83] H. Kawai, H. Li, S. Avraham, S. Jiang, and H. K. Avraham, "Overexpression of histone deacetylase HDAC1 modulates breast cancer progression by negative regulation of estrogen receptor $\alpha$, International Journal of Cancer, vol. 107, no. 3, pp. 353-358, 2003.

[84] R. Metivier, G. Penot, M. R. Hubner et al., "Estrogen receptor- $\alpha$ directs ordered, cyclical, and combinatorial recruitment of cofactors on a natural target promoter," Cell, vol. 115, no. 6, pp. 751-763, 2003.

[85] Y. Shang and M. Brown, "Molecular determinants for the tissue specificity of SERMs," Science, vol. 295, no. 5564, pp. 2465-2468, 2002.

[86] H. Leong, J. R. Sloan, P. D. Nash, and G. L. Greene, "Recruitment of histone deacetylase 4 to the N-terminal region of estrogen receptor $\alpha$," Molecular Endocrinology, vol. 19, no. 12, pp. 2930-2942, 2005.

[87] E. Van Rooij, J. Fielitz, L. B. Sutherland et al., "Myocyte enhancer factor 2 and class ii histone deacetylases control a gender-specific pathway of cardioprotection mediated by the estrogen receptor," Circulation Research, vol. 106, no. 1, pp. 155-165, 2010.

[88] K. Azuma, T. Urano, K. Horie-Inoue et al., "Association of estrogen receptor a and histone deacetylase 6 causes rapid deacetylation of tubulin in breast cancer cells," Cancer Research, vol. 69, no. 7, pp. 2935-2940, 2009.

[89] W. Fiskus, Y. Ren, A. Mohapatra et al., "Hydroxamic acid analogue histone deacetylase inhibitors attenuate estrogen receptor- $\alpha$ levels and transcriptional activity: a result of hyperacetylation and inhibition of chaperone function of heat shock protein 90," Clinical Cancer Research, vol. 13, no. 16, pp. 4882-4890, 2007.

[90] S. Malik, S. Jiang, J. P. Garee et al., "Histone deacetylase 7 and FoxA1 in estrogen-mediated repression of RPRM," Molecular and Cellular Biology, vol. 30, no. 2, pp. 399-412, 2010.

[91] Y. Yao, H. Li, Y. Gu, N. E. Davidson, and Q. Zhou, "Inhibition of SIRT1 deacetylase suppresses estrogen receptor signaling," Carcinogenesis, vol. 31, no. 3, pp. 382-387, 2009.

[92] V. Chopin, C. Slomianny, H. Hondermarck, and X. Le Bourhis, "Synergistic induction of apoptosis in breast cancer cells by cotreatment with butyrate and TNF-alpha, TRAIL, or anti-Fas agonist antibody involves enhancement of death receptors' signaling and requires $\mathrm{P} 21^{\text {wafl }}$," Experimental Cell Research, vol. 298, no. 2, pp. 560-573, 2004.

[93] S. Nakata, T. Yoshida, M. Horinaka, T. Shiraishi, M. Wakada, and T. Sakai, "Histone deacetylase inhibitors upregulate death receptor 5/TRAIL-R2 and sensitize apoptosis induced by TRAIL/APO2-L in human malignant tumor cells," Oncogene, vol. 23, no. 37, pp. 6261-6271, 2004.

[94] T. R. Singh, S. Shankar, and R. K. Srivastava, "HDAC inhibitors enhance the apoptosis-inducing potential of TRAIL in breast carcinoma," Oncogene, vol. 24, no. 29, pp. 4609-4623, 2005.

[95] A. J. Frew, R. K. Lindemann, B. P. Martin et al., "Combination therapy of established cancer using a histone deacetylase inhibitor and a TRAIL receptor agonist," Proceedings of the National Academy of Sciences of the United States of America, vol. 105, no. 32, pp. 11317-11322, 2008.

[96] S. Shankar, R. Davis, K. P. Singh, R. Kurzrock, D. D. Ross, and R. K. Srivastava, "Suberoylanilide hydroxamic acid (Zolinza/vorinostat) sensitizes TRAIL-resistant breast cancer cells orthotopically implanted in BALB/c nude mice," Molecular Cancer Therapeutics, vol. 8, no. 6, pp. 1596-1605, 2009.

[97] Y. Hirokawa, M. Arnold, H. Nakajima, J. Zalcberg, and H. Maruta, "Signal therapy of breast cancers by the HDAC inhibitor FK228 that blocks the activation of PAK1 and abrogates the tamoxifen-resistance," Cancer Biology and Therapy, vol. 4, no. 9, pp. 956-960, 2005.

[98] J. Fan, W. J. Yin, J. S. Lu et al., "ER $\alpha$ negative breast cancer cells restore response to endocrine therapy by combination treatment with both HDAC inhibitor and DNMT inhibitor," Journal of Cancer Research and Clinical Oncology, vol. 134, no. 8, pp. 883-890, 2008.

[99] D. Palmieri, P. R. Lockman, F. C. Thomas et al., "Vorinostat inhibits brain metastatic colonization in a model of triplenegative breast cancer and induces DNA double-strand breaks," Clinical Cancer Research, vol. 15, no. 19, pp. 61486157, 2009.

[100] R. Margueron, V. Duong, S. Bonnet et al., "Histone deacetylase inhibition and estrogen receptor $\alpha$ levels modulate the transcriptional activity of partial antiestrogens," Journal of Molecular Endocrinology, vol. 32, no. 2, pp. 583-594, 2004. 
[101] A. DeFazio, Y. E. Chiew, C. Donoghue, C. S. L. Lee, and R. L. Sutherland, "Effect of sodium butyrate on estrogen receptor and epidermal growth factor receptor gene expression in human breast cancer cell lines," Journal of Biological Chemistry, vol. 267, no. 25, pp. 18008-18012, 1992.

[102] G. Reid, R. Metivier, C. Y. Lin et al., "Multiple mechanisms induce transcriptional silencing of a subset of genes, including oestrogen receptor $\alpha$, in response to deacetylase inhibition by valproic acid and trichostatin A," Oncogene, vol. 24, no. 31, pp. 4894-4907, 2005.

[103] W. Rocha, R. Sanchez, J. Deschenes et al., "Opposite effects of histone deacetylase inhibitors on glucocorticoid and estrogen signaling in human endometrial ishikawa cells," Molecular Pharmacology, vol. 68, no. 6, pp. 1852-1862, 2005.

[104] M. Kos, G. Reid, S. Denger, and F. Gannon, "Minireview: genomic organization of the human ER $\alpha$ gene promoter region," Molecular Endocrinology, vol. 15, no. 12, pp. 20572063, 2001.

[105] P. Pryzbylkowski, O. Obajimi, and J. C. Keen, "Trichostatin A and 5 Aza-2' deoxycytidine decrease estrogen receptor mRNA stability in ER positive MCF7 cells through modulation of HuR," Breast Cancer Research and Treatment, vol. 111, no. 1, pp. 15-25, 2008.

[106] C. M. Klinge, "Estrogen regulation of microRNA expression," Current Genomics, vol. 10, no. 3, pp. 169-183, 2009.

[107] A. E. Fliss, S. Benzeno, J. Rao, and A. J. Caplan, "Control of estrogen receptor ligand binding by Hsp90," Journal of Steroid Biochemistry and Molecular Biology, vol. 72, no. 5, pp. 223230, 2000.

[108] L. Whitesell and S. L. Lindquist, "HSP90 and the chaperoning of cancer," Nature Reviews Cancer, vol. 5, no. 10, pp. 761-772, 2005.

[109] X. Yi, W. Wei, S. Y. Wang, Z. Y. Du, Y. J. Xu, and $\mathrm{X}$. D. Yu, "Histone deacetylase inhibitor SAHA induces $\mathrm{ER} \alpha$ degradation in breast cancer MCF-7 cells by CHIPmediated ubiquitin pathway and inhibits survival signaling," Biochemical Pharmacology, vol. 75, no. 9, pp. 1697-1705, 2008.

[110] S. H. Kim, H. J. Kang, H. Na, and M. O. Lee, "Trichostatin A enhances acetylation as well as protein stability of ERalpha through induction of p300 protein," Breast Cancer Research, vol. 12, no. 2. article no. R22, 2010.

[111] X. Yang, A. T. Ferguson, S. J. Nass et al., "Transcriptional activation of estrogen receptor $\alpha$ in human breast cancer cells by histone deacetylase inhibition," Cancer Research, vol. 60, no. 24, pp. 6890-6894, 2000.

[112] N. Fortunati, S. Bertino, L. Costantino et al., "Valproic acid restores $\mathrm{ER} \alpha$ and antiestrogen sensitivity to $\mathrm{ER} \alpha$-negative breast cancer cells," Molecular and Cellular Endocrinology, vol. 314, no. 1, pp. 17-22, 2010.

[113] X. Yang, D. L. Phillips, A. T. Ferguson, W. G. Nelson, J. G. Herman, and N. E. Davidson, "Synergistic activation of functional estrogen receptor (ER)- $\alpha$ by DNA methyltransferase and histone deacetylase inhibition in human ER- $\alpha$-negative breast cancer cells," Cancer Research, vol. 61, no. 19, pp. 70257029, 2001.

[114] J. C. Keen, L. Yan, K. M. Mack et al., "A novel histone deacetylase inhibitor, Scriptaid, enhances expression of functional estrogen receptor $\alpha$ (ER) in ER negative human breast cancer cells in combination with 5-aza 2'-deoxycytidine," Breast Cancer Research and Treatment, vol. 81, no. 3, pp. 177-186, 2003.
[115] M. Macaluso, C. Cinti, G. Russo, A. Russo, and A. Giordano, "pRb2/p130-E2F4/5-HDAC1-SUV39H1-p300 and pRb2/ p130-E2F4/5-HDAC1-SUV39H1-DNMT1 multimolecular complexes mediate the transcription of estrogen receptor- $\alpha$ in breast cancer," Oncogene, vol. 22, no. 23, pp. 3511-3517, 2003.

[116] G. W. Woodfield, M. J. Hitchler, Y. Chen, F. E. Domann, and R. J. Weigel, "Interaction of TFAP2C with the estrogen receptor- $\alpha$ promoter is controlled by chromatin structure," Clinical Cancer Research, vol. 15, no. 11, pp. 3672-3679, 2009.

[117] Q. Zhou, P. Atadja, and N. E. Davidson, "Histone deacetylase inhibitor LBH589 reactivates silenced estrogen receptor alpha (ER) gene expression without loss of DNA hypermethylation," Cancer Biology and Therapy, vol. 6, no. 1, pp. 6469, 2007.

[118] Q. Zhou, P. G. Shaw, and N. E. Davidson, "Inhibition of histone deacetylase suppresses EGF signaling pathways by destabilizing EGFR mRNA in ER-negative human breast cancer cells," Breast Cancer Research and Treatment, vol. 117, no. 2, pp. 443-451, 2009.

[119] O. I. W. S. Yap, G. Bhat, L. Liu, and T. O. Tollefsbol, "Epigenetic modifications of the estrogen receptor $\beta$ gene in epithelial ovarian cancer cells," Anticancer Research, vol. 29, no. 1, pp. 139-144, 2009.

[120] T. J. Walton, G. Li, R. Seth, S. E. McArdle, M. C. Bishop, and R. C. Rees, "DNA demethylation and histone deacetylation inhibition co-operate to re-express estrogen receptor beta and induce apoptosis in prostate cancer cell-lines," Prostate, vol. 68, no. 2, pp. 210-222, 2008.

[121] E. R. Jang, S. J. Lim, E. S. Lee et al., "The histone deacetylase inhibitor trichostatin a sensitizes estrogen receptor $\alpha$ negative breast cancer cells to tamoxifen," Oncogene, vol. 23, no. 9, pp. 1724-1736, 2004.

[122] V. Duong, A. Licznar, R. Margueron et al., "ER $\alpha$ and $\mathrm{ER} \beta$ expression and transcriptional activity are differentially regulated by HDAC inhibitors," Oncogene, vol. 25, no. 12, pp. 1799-1806, 2006.

[123] H. Faus and B. Haendler, "Post-translational modifications of steroid receptors," Biomedicine and Pharmacotherapy, vol. 60, no. 9, pp. 520-528, 2006.

[124] M. Fu, C. Wang, A. T. Reutens et al., "p300 and p300/cAMPresponse element-binding protein-associated factor acetylate the androgen receptor at sites governing hormonedependent transactivation," Journal of Biological Chemistry, vol. 275, no. 27, pp. 20853-20860, 2000.

[125] A. L. Jacob, J. Lund, P. Martinez, and L. Hedin, "Acetylation of steroidogenic factor 1 protein regulates its transcriptional activity and recruits the coactivator GCN5," Journal of Biological Chemistry, vol. 276, no. 40, pp. 37659-37664, 2001.

[126] C. Wang, M. Fu, R. H. Angeletti et al., "Direct acetylation of the estrogen receptor alpha hinge region by p 300 regulates transactivation and hormone sensitivity," Journal of Biological Chemistry, vol. 276, no. 21, pp. 18375-18383, 2001.

[127] Y. M. Kim, E. M. Woo, Y. T. E. Chong, D. R. Homenko, and W. L. Kraus, "Acetylation of estrogen receptor $\alpha$ by p300 at lysines 266 and 268 enhances the deoxyribonucleic acid binding and transactivation activities of the receptor," Molecular Endocrinology, vol. 20, no. 7, pp. 1479-1493, 2006.

[128] H. Chen, R. J. Lin, W. Xie, D. Wilpitz, and R. M. Evans, "Regulation of hormone-induced histone hyperacetylation and gene activation via acetylation of an acetylase," Cell, vol. 98, no. 5, pp. 675-686, 1999. 
[129] C. Lerin, J. T. Rodgers, D. E. Kalume, S. H. Kim, A. Pandey, and P. Puigserver, "GCN5 acetyltransferase complex controls glucose metabolism through transcriptional repression of PGC-1 $\alpha$," Cell Metabolism, vol. 3, no. 6, pp. 429-438, 2006.

[130] N. Vo, C. Fjeld, and R. H. Goodman, "Acetylation of nuclear hormone receptor-interacting protein RIP140 regulates binding of the transcriptional corepressor CtBP," Molecular and Cellular Biology, vol. 21, no. 18, pp. 6181-6188, 2001.

[131] Y. Qiu, Y. Zhao, M. Becker et al., "HDAC1 acetylation is linked to progressive modulation of steroid receptor-induced gene transcription," Molecular Cell, vol. 22, no. 5, pp. 669 679, 2006.

[132] A. Castet, A. Boulahtouf, G. Versini et al., "Multiple domains of the receptor-interacting protein 140 contribute to transcription inhibition," Nucleic Acids Research, vol. 32, no. 6, pp. 1957-1966, 2004.

[133] M. Christian, J. M. A. Tullet, and M. G. Parker, "Characterization of four autonomous repression domains in the corepressor receptor interacting protein 140," Journal of Biological Chemistry, vol. 279, no. 15, pp. 15645-15651, 2004.

[134] LI. N. Wei, M. Farooqui, and X. Hu, "Ligand-dependent formation of retinoid receptors, receptor-interacting protein 140 (RIP140), and histone deacetylase complex is mediated by a novel receptor-interacting motif of RIP140," Journal of Biological Chemistry, vol. 276, no. 19, pp. 16107-16112, 2001.

[135] J. Gobinet, S. Carascossa, V. Cavailles, F. Vignon, J. C. Nicolas, and S. Jalaguier, "SHP represses transcriptional activity via recruitment of histone deacetylases," Biochemistry, vol. 44, no. 16, pp. 6312-6320, 2005.

[136] V. Kurtev, R. Margueron, K. Kroboth, E. Ogris, V. Cavailles, and C. Seiser, "Transcriptional regulation by the repressor of estrogen receptor activity via recruitment of histone deacetylases," Journal of Biological Chemistry, vol. 279, no. 23, pp. 24834-24843, 2004.

[137] J. Li, J. Wang, J. Wang et al., "Both corepressor proteins SMRT and $\mathrm{N}-\mathrm{CoR}$ exist in large protein complexes containing HDAC3," EMBO Journal, vol. 19, no. 16, pp. 4342-4350, 2000.

[138] M. G. Guenther, O. Barak, and M. A. Lazar, "The SMRT and N-CoR corepressors are activating cofactors for histone deacetylase 3," Molecular and Cellular Biology, vol. 21, no. 18, pp. 6091-6101, 2001.

[139] H. Li, G. K. Rajendran, N. Liu, C. Ware, B. P. Rubin, and Y. Gu, "SirT1 modulates the estrogen-insulin-like growth factor-1 signaling for postnatal development of mammary gland in mice," Breast Cancer Research, vol. 9, no. 1, article no. R1, 2007.

[140] L. Hodges-Gallagher, C. D. Valentine, S. E. Bader, and P. J. Kushner, "Estrogen receptor beta increases the efficacy of antiestrogens by effects on apoptosis and cell cycling in breast cancer cells," Breast Cancer Research and Treatment, vol. 109, no. 2, pp. 241-250, 2008.

[141] S. K. Rayala, A. H. Talukder, S. Balasenthil et al., "P21activated kinase 1 regulation of estrogen receptor- $\alpha$ activation involves serine 305 activation linked with serine 118 phosphorylation," Cancer Research, vol. 66, no. 3, pp. 16941701, 2006.

[142] Q. Zhou, P. G. Shaw, and N. E. Davidson, "Inhibition of histone deacetylase suppresses EGF signaling pathways by destabilizing EGFR mRNA in ER-negative human breast cancer cells," Breast Cancer Research and Treatment, vol. 117, no. 2, pp. 443-451, 2009.
[143] T. H. Luu, R. J. Morgan, L. Leong et al., "A phase II trial of vorinostat (suberoylanilide hydroxamic acid) in metastatic breast cancer: a California cancer consortium study," Clinical Cancer Research, vol. 14, no. 21, pp. 7138-7142, 2008.

[144] C. J. Lai, R. Bao, XU. Tao et al., "CUDC-101, a multitargeted inhibitor of histone deacetylase, epidermal growth factor receptor, and human epidermal growth factor receptor 2, exerts potent anticancer activity," Cancer Research, vol. 70, no. 9, pp. 3647-3656, 2010.

[145] S. Mahboobi, S. Dove, A. Sellmer et al., "Design of chimeric histone deacetylase- and tyrosine kinase-inhibitors: a series of Imatinib hybrides as potent Inhibitors of wild-type and mutant BCR-ABL, PDGF-R $\beta$, and histone deacetylases," Journal of Medicinal Chemistry, vol. 52, no. 8, pp. 2265-2279, 2009.

[146] X. Cai, H. X. Zhai, J. Wang et al., "Discovery of 7-(4-(3Ethynylphenylamino)-7-methoxyquinazolin-6-yloxy)-Nhydroxyheptanamide (CUDC-101) as a potent multi-acting HDAC, EGFR, and HER2 inhibitor for the treatment of cancer," Journal of Medicinal Chemistry, vol. 53, no. 5, pp. 2000-2009, 2010. 

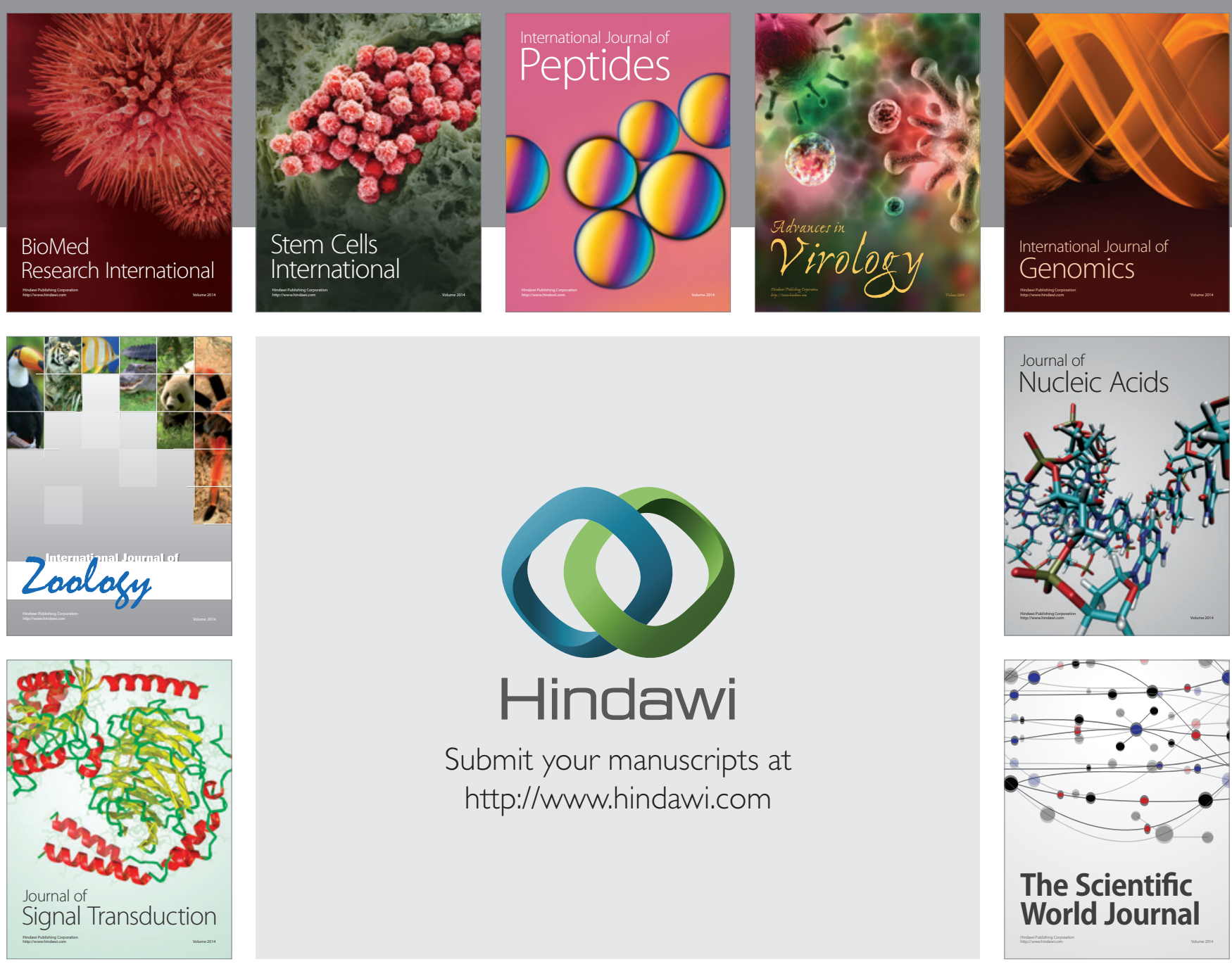

Submit your manuscripts at

http://www.hindawi.com
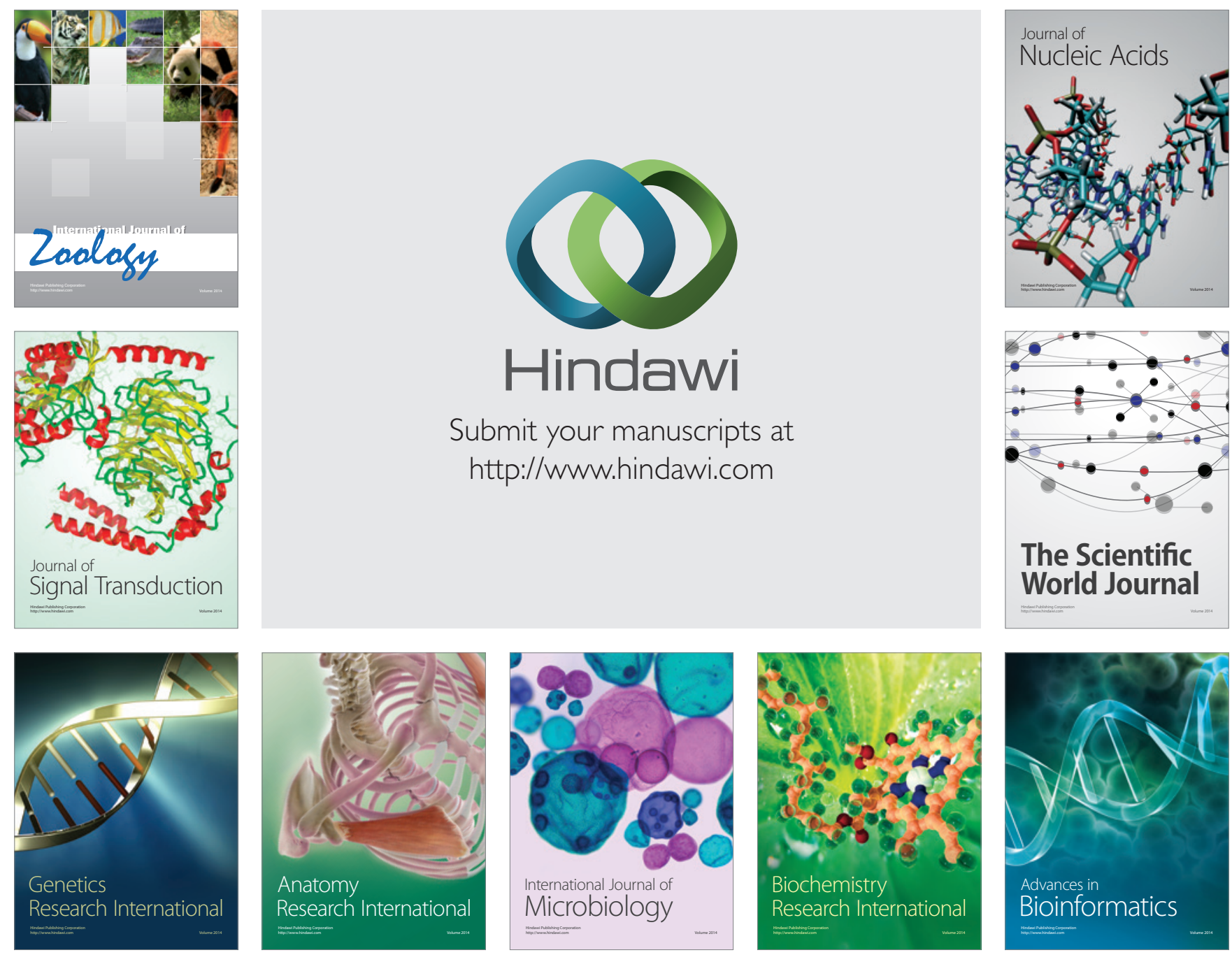

The Scientific World Journal
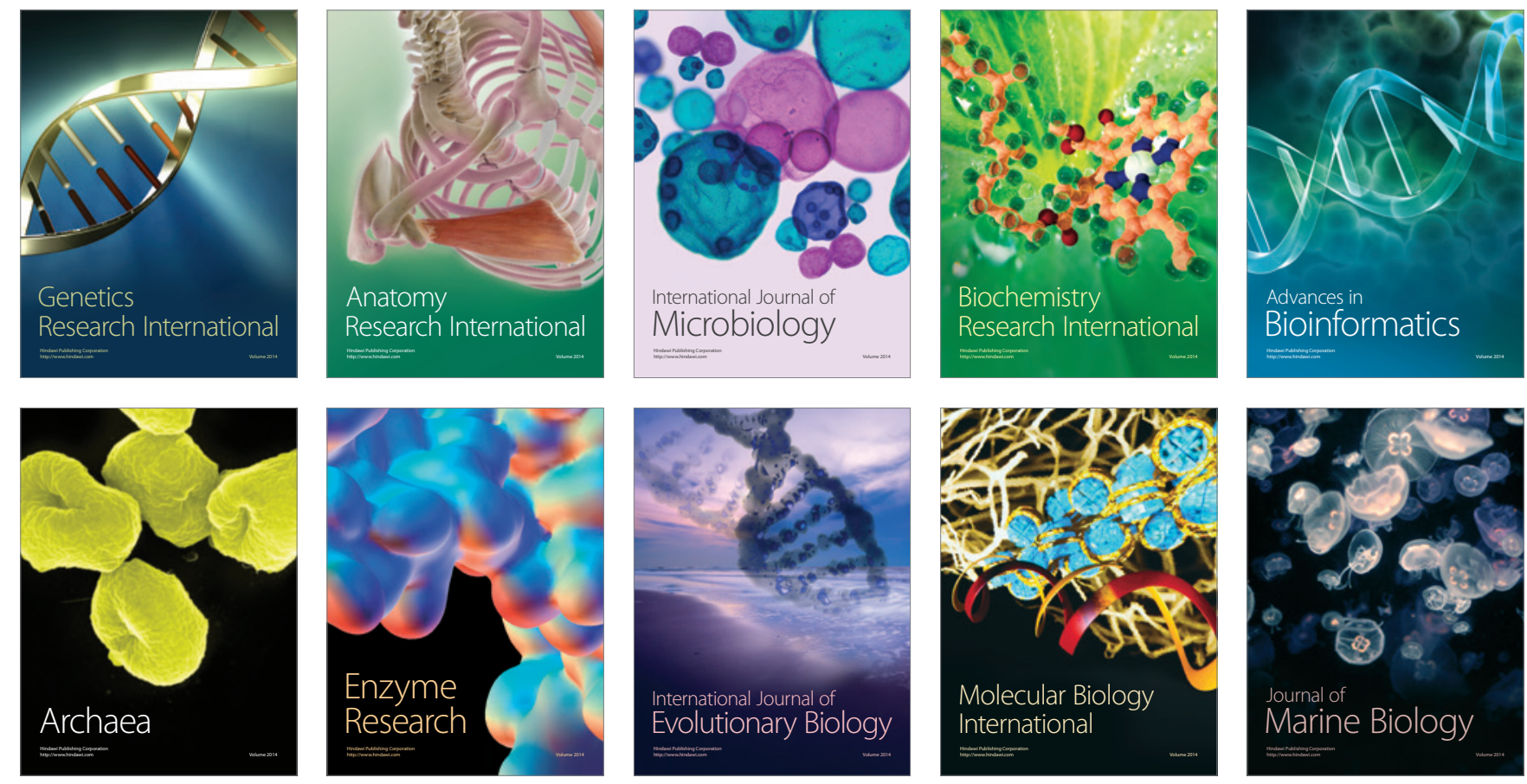